\title{
The Brass Nails of the Akko Tower Wreck (Israel): Archaeometallurgical Analyses
}

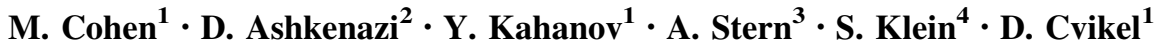

Received: 1 January 2015/Revised: 24 March 2015/Accepted: 1 April 2015/Published online: 24 April 2015

(C) Springer Science+Business Media New York and ASM International 2015

\begin{abstract}
The shipwreck designated as the Akko Tower Wreck was discovered inside Akko harbor, Israel, in 1966. It was surveyed in 1975 and 1981, and excavated in 2012-2013. Hull planks were connected to the frames by brass nails, some of which were in situ, emerging vertically from the planking, where frames had disappeared, and others were detached. The 105 nails that were retrieved were tentatively divided into two groups (A and B) according to their general shape and size. Nails sampled from each group were characterized by non-destructive and destructive metallurgical methods, including XRF, light microscopy, SEMEDS, microindentation hardness measurements, and lead isotope analysis, in order to reveal their composition and microstructure, as well as to determine their manufacturing process and date the origin of the raw material. All nails were manufactured by casting and made of binary copper-zinc alloy: Type A with 35-36 wt\% zinc, and Type B with 33$34 \mathrm{wt} \%$ zinc (XRF results). These compositions confirmed the preliminary typing of the nails. Their microstructure indicates that they were manufactured differently: Type A nails have Widmanstätten thin lamellae plates, and Type B nails have $\alpha$-brass grains containing a dendritic
\end{abstract}

D. Ashkenazi

dana@eng.tau.ac.il

1 Leon Recanati Institute for Maritime Studies, University of Haifa, 3498838 Haifa, Israel

2 School of Mechanical Engineering, Tel Aviv University, 6997801 Ramat Aviv, Israel

3 Department of Materials Engineering, Ben-Gurion University of the Negev, 8410501 Beer Sheva, Israel

4 Institut für Geowissenschaften, J. W. Goethe Universität, Altenhöferallee 1, 60438 Frankfurt, Germany microstructure. Based on their zinc and lead concentrations it is suggested that the nails were manufactured in the first half of the nineteenth century. The lead isotope analyses of the nails suggest that the raw material most probably originated in Great Britain. Hence, it is suggested that the Akko Tower Wreck is the remains of a European merchantman which sank in Akko harbor about the middle of the nineteenth century.

Keywords Akko Tower Wreck · Brass nails · Casting · Lead isotope $\cdot$ Microstructure $\cdot$ Metallography

\section{Introduction}

\section{The Historical Setting}

The historic walled port city of Akko (Acre, St. Jean d'Acre, Akka) lies at the northern extremity of Haifa Bay, in the north of Israel (Fig. 1). It has a continuous settlement history from the Early Bronze Age to the modern era, serving as an important port [1-3]. The town and harbor were conquered by the Ottomans in 1516 [3].

The restoration and fortification of the town was begun by Daher al-Umar in the mid-eighteenth century [3, 4, p. 133]. In the second half of the eighteenth century, Akko became the de facto capital of the Holy Land, as well as its principal trading port [4, p. 134]. In August 1775 Ahmed Jezzar Pasha captured Akko, and made it the center of his authority. By the late 1780s Jezzar Pasha had a small fleet of seven warships, some of which were merchantmen which he armed with cannon salvaged from shipwrecks [4, pp. 290-291].

In 1799, British control of the sea and the harbor of Akko with its fortifications and defenders prevented 
Fig. 1 Location of Akko and the Akko Tower Wreck (Drawing: N. Yoselevich and J. Asuli)
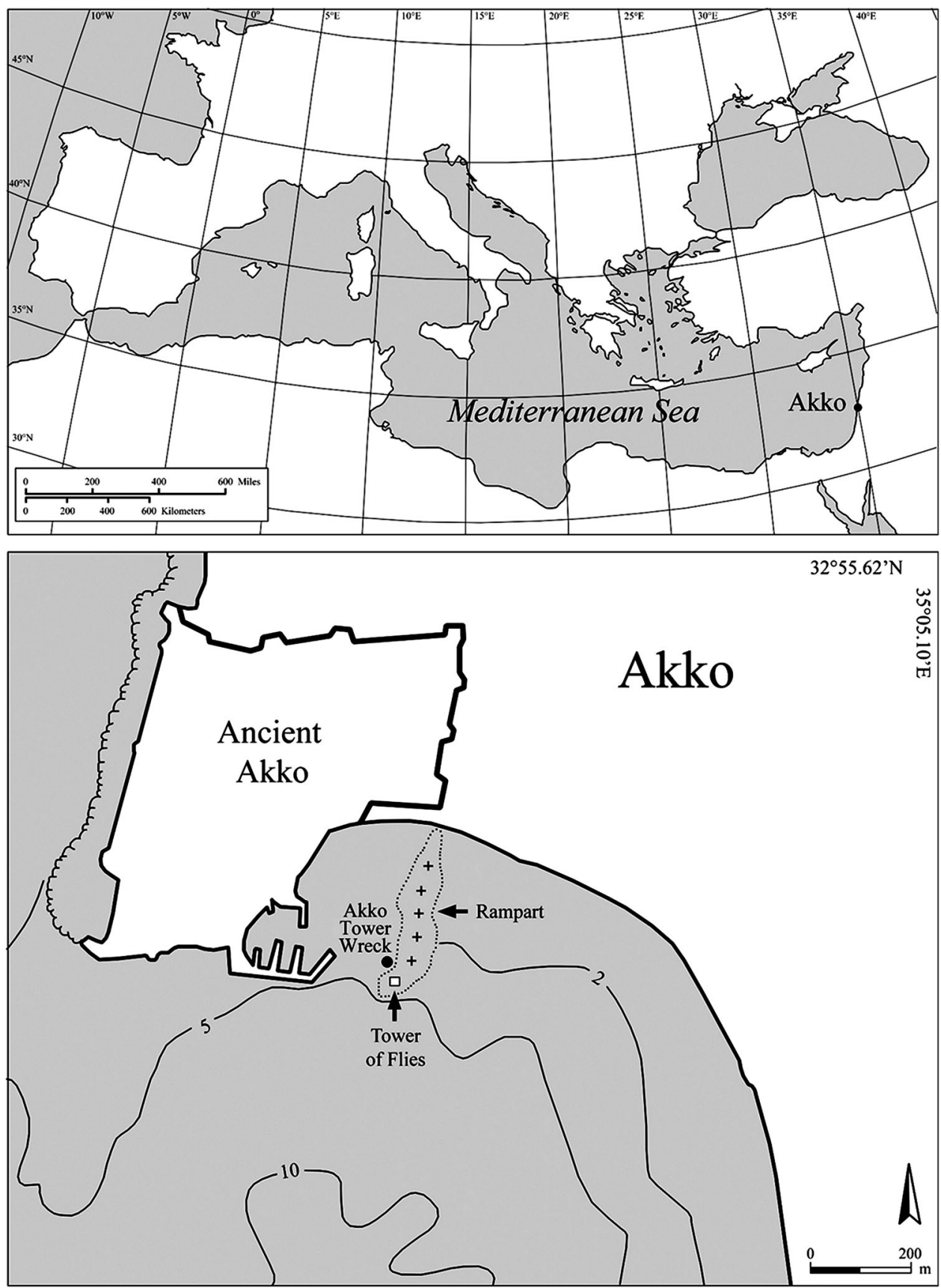

Napoleon Bonaparte from taking the town and stopped his advance northwards [5, p. 28, 6, pp. 372-373, 7]. Muhammad Ali's Egyptian flotilla bombarded Akko heavily in December 1831. The defenders of Akko withstood the attack from the sea, and the Egyptian ships were severely damaged. After a 6-month siege, on 27 May 1832, the Egyptians took the town by land. The period of Egyptian rule over Akko lasted until 3 November 1840, when a British-Austrian-Ottoman fleet bombarded the town. During this attack, the main powder magazine of Akko exploded, causing enormous damage to the town, which was taken the following day [5, pp. 39-48, 6, pp. 561-564, 8].

Although the town was heavily damaged and her fortifications destroyed, ships continued to call at the harbor, which was also a starting point for research expeditions to the Holy Land. For example, in August 1847, T. H. Molyneux launched an expedition from the 26-gun frigate HMS Spartan, to the Dead Sea from Akko [9]. In March-April 1848, the USS Supply anchored near Akko, from where W. F. Lynch started his expedition to the Jordan and the Dead Sea [10, 11]. In 1860, A. L. Mansell, 
with HMS Firefly, surveyed the bay of Akko and the town [12].

These land and naval campaigns were a result of Akko being considered the key to the Holy Land and Syria, and its conquest marked the change of control over the whole country. At the same time, Akko harbor served for commercial purposes and for survey expeditions. Consequently, ships of various types, and from various fleetsEuropean, American, and eastern Mediterranean, used Akko harbor. The Akko Tower Wreck is probably the remains of one of these ships.

\section{The Akko Tower Wreck}

The shipwreck designated as the Akko Tower Wreck lies at the entrance to Akko harbor, 35 m north of the Tower of Flies, after which it was named (Fig. 1). It was discovered in 1966, and surveyed twice, in 1975 and 1981 [13, 14]. The researchers who surveyed the shipwreck came to two different conclusions regarding the original ship: (1) it was a 45-m-long warship, which was scuttled by the British during the French siege of Akko in 1799 [13, 14]; and (2) it was a 25-m-long European merchantman from the nineteenth century [15]. Following the discrepancies in their conclusions, and the scholars' wish that the Akko Tower Wreck be further studied, it was excavated in 2012-2013 by the Leon Recanati Institute for Maritime Studies of the University of Haifa.

The Akko Tower Wreck was found in $4.4 \mathrm{~m}$ of water. The shipwreck remains, lying north-east to south-west, were $17.8 \mathrm{~m}$ between its extremities, and maximum $6.4 \mathrm{~m}$ wide. Among the hull remains were sections of the keel, rising wood, keelson, hull planks, framing timbers, ceiling planks, and limber boards. Hull components were made of pine (Pinus) and oak (Quercus) species.

\section{The Brass Nails}

During the underwater excavations, a total of 105 brass nails were retrieved from the wreck-site. The majority of nails $(81 \%)$ were found detached, scattered inside the shipwreck and nearby, probably as a result of the wrecking or degradation of the wood over the years, while some (19\%) were removed from the wooden components (Fig. 2). Following a preliminary examination, it was seen that all nails had a square cross-section and a round head, so they should be referred to as 'spikes': "a large, cut or [hand] wrought nail of square section made of galvanized iron, steel, or composition" [16, p. 176]. Their ends were not pointed, but rather chisel-shaped. They were driven in with the wide side of the end perpendicular to the wood (plank) grain.

The nails were divided tentatively into two groups, based on their dimensions (Fig. 3). Nine nails were poorly preserved, and were not placed into a certain group, as well

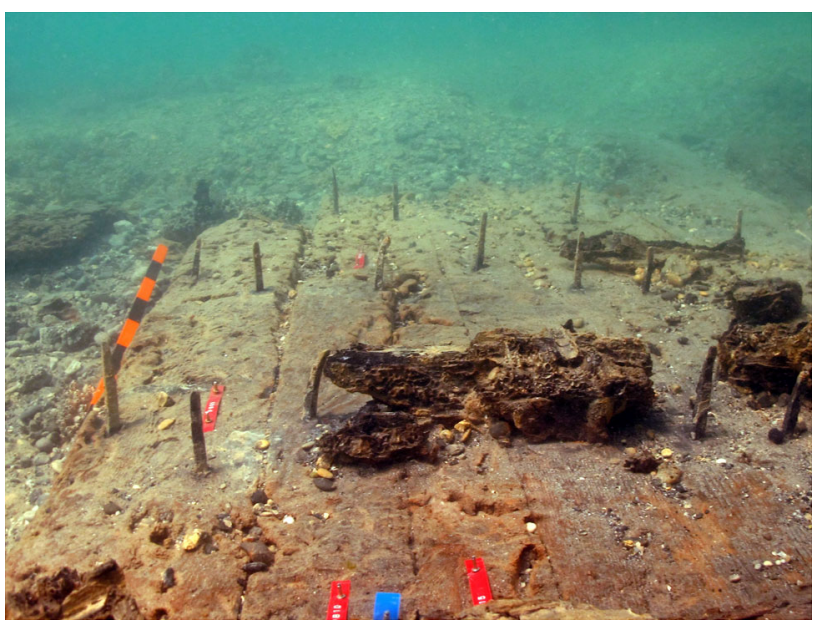

Fig. 2 The brass nails as found in the hull planks. These nails were used to connect the hull planks to the framing timbers (Photo: A. Yurman)

as two small nails (3.5 cm long) and six miscellaneous nails, which are not included in this study. Later, this classification was found to be correct (see below):

1. Type A-long shank, with an average length of $102.4 \mathrm{~mm}$ (Table 1). The group contained 68 nails, of which three were examined: numbers $135,155.1$, and 160.1 (these are the archaeological catalog numbers).

2. Type B-short shank, with an average length of $65.9 \mathrm{~mm}$ (Table 2). The group contained 20 nails, of which three were examined: numbers $139,148.2$, and 159 .

Following an XRF chemical analysis of two nails (areas of each nail were examined), one from each group, the results (discussed in detail in "Results" section) indicate that the two groups had different compositions, and confirm the typological classification. This initiated the study and examination of the nail characterization, composition, and microstructure.

Establishing and comparing the microstructure, chemical composition and properties of the nails provide information on their manufacturing processes and date and on the possible origin of the raw materials by geochemical lead isotope investigation. This provides new information on the Akko Tower Wreck, as well as adding to the existing database related to metal objects from other shipwrecks of the period.

\section{Metallurgical Background to Research}

Brass, a copper-zinc alloy, has been used since the Roman period [17-19, p. 71], although its alloying process was not completely understood prior to the middle of the eighteenth 
Fig. 3 The examined brass nails from Akko Tower Wreck (Photos: J. J. Gottlieb and M. Cohen, Drawing: R. Pollak)
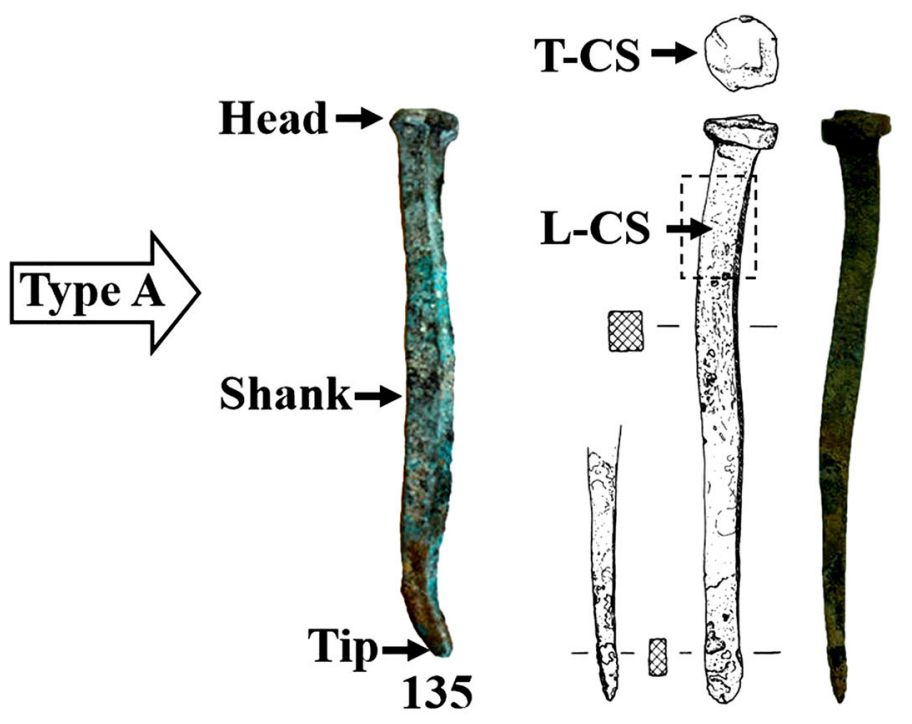

155.1
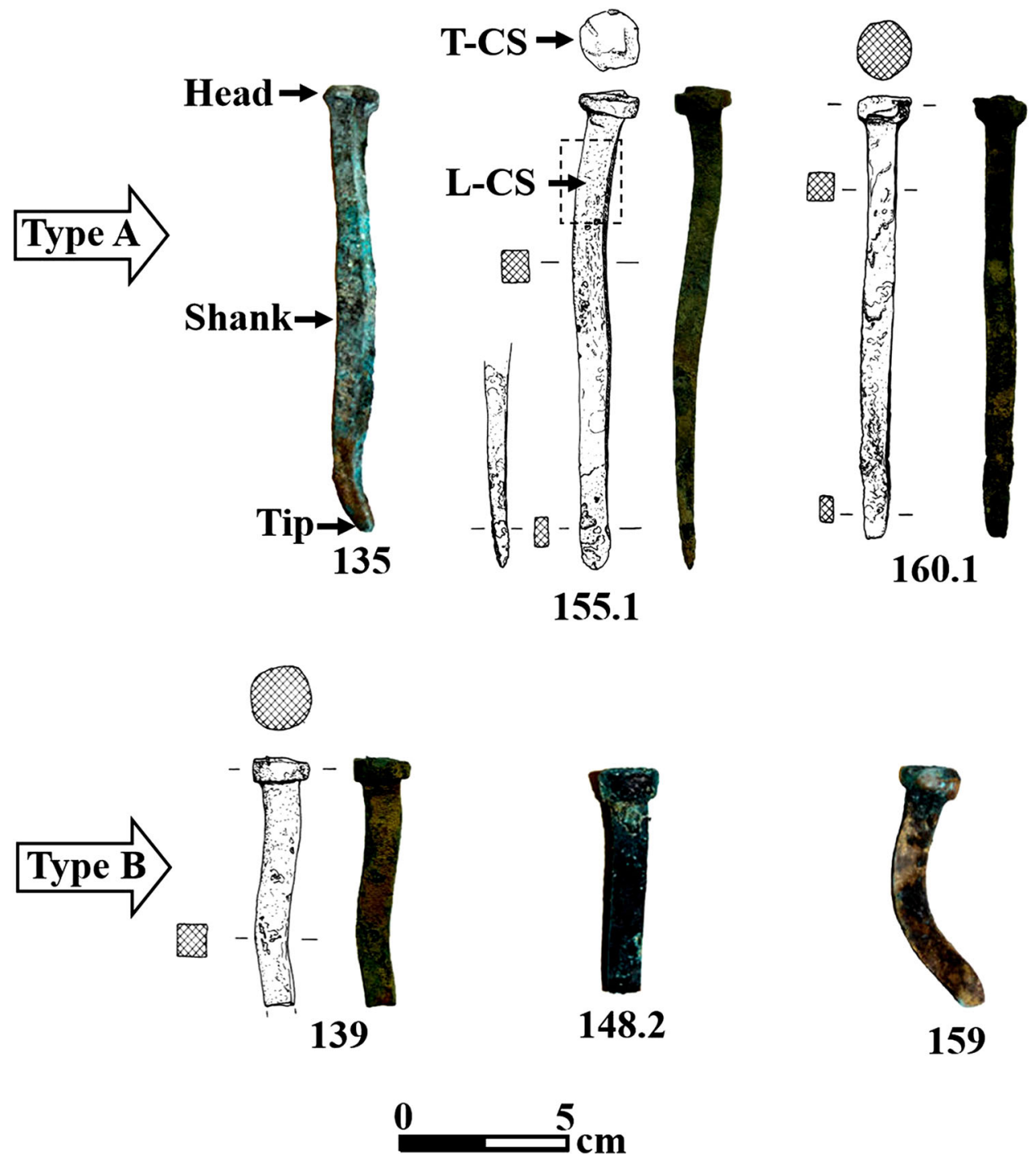

Tables 1 Average dimensions and weight of all brass nails according to their type

\begin{tabular}{lllll}
\hline Nail type & $\begin{array}{l}\text { Number } \\
\text { of nails }\end{array}$ & $\begin{array}{l}\text { Average } \\
\text { length }(\mathrm{mm})\end{array}$ & $\begin{array}{l}\text { Typical head } \\
\text { diameter }(\mathrm{mm})\end{array}$ & $\begin{array}{l}\text { Average cross-section in the } \\
\text { middle of shank }(\mathrm{mm})\end{array}$ \\
\hline Type A & 68 & 102.4 & 16 & $8.4 \times 9.6$ \\
Type B & 20 & 65.9 & 16.5 & $8.6 \times 9.4$ \\
\hline
\end{tabular}

century [20, 21, p. 28]. Brass is widely used due to its useful properties: it is easily shaped, and can be softened by heating, and hardened by cold-working, as well as being easily joined by soldering [21, p. 32].

Brass with less than $39 \mathrm{wt} \% \mathrm{Zn}$ usually solidifies as a solid solution of $\alpha$-brass: it is bright, ductile, and easily shaped. Brass with more than $39 \mathrm{wt} \% \mathrm{Zn}$ solidifies as a two-phase alloy: $\alpha+\beta$ [22]. The brass properties may be improved by adding alloying elements; for instance, lead improves castability and machinability [18, 23, 24]. Such leaded brasses may have been manufactured deliberately or unintentionally depending on the presence of lead-rich minerals in the ore [17, 22].

The cementation process, which produced brass with up to $28 \mathrm{wt} \% \mathrm{Zn}$, was used until the early nineteenth century [25, p. 183,26 , p. 16, 27, p. 19], although in 1859 there were still several copper works using this process [28, p. 612]. The widespread zinc mineral, calamine [zinc oxide that contains about $0.5 \mathrm{wt} \%$ iron oxide $\left(\mathrm{Fe}_{2} \mathrm{O}_{3}\right)$, was used in Europe for the cementation process, and as a result the brass often contained up to $0.5 \mathrm{wt} \% \mathrm{Fe}[17]$. 
Tables 2 Dimensions and weight of the brass nails examined in the current study

\begin{tabular}{llllll}
\hline $\begin{array}{l}\text { Nail number } \\
\text { and type }\end{array}$ & $\begin{array}{l}\text { Length } \\
(\mathrm{mm})\end{array}$ & $\begin{array}{l}\text { Diameter of } \\
\text { head }(\mathrm{mm})\end{array}$ & $\begin{array}{l}\text { Shank (top) } \\
\text { cross-section }(\mathrm{mm})\end{array}$ & $\begin{array}{l}\text { Shank (middle) } \\
\text { cross-section (mm) }\end{array}$ & $\begin{array}{l}\text { Tip or shank/tip } \\
\text { cross-section }(\mathrm{mm})\end{array}$ \\
\hline 135 (Type A) & 129.1 & $13.5 \times 14.3$ & $6.6 \times 7.2$ & $7.3 \times 8.4$ & $2.6 \times 6.8$ \\
$(\mathrm{~g})$
\end{tabular}

When recycled, the percentage of $\mathrm{Zn}$ in the new objects was relatively low (usually a few wt $\%$ zinc), due to the loss of about $10 \mathrm{wt} \%$ of zinc each time the brass was recycled [17]. In 1738 in Great Britain, W. Champion patented a method for the industrial production of metallic zinc by the distillation process, which was used in direct alloying (speltering technique)—a post-cementation method [29]. In this process, metallic zinc was added to the copper, and the brass produced contained more than $30 \mathrm{wt} \% \mathrm{Zn}[30$, pp. 53-55].

Since the direct alloying proved rudimentary and unprofitable, and the production of brass by cementation was successful, the latter remained the common production method until the early nineteenth century [25-27, p. 19, 31]. According to Mitchiner et al. [32], speltered brass began to supplant the calamine process in 1830. This happened due to the increased scale of European zinc production in the early nineteenth century, and the easing of English import tariffs in 1830.

Metals usually shrink by 3-8\% when they solidify, leading to shrinkage porosity [33]. Common casting defects, such as porosity and shrinkage, depend on the method and conditions under which the alloys were cast and solidified [34]. By casting copper-zinc alloys, a better filling of the mold could be achieved. The alloy's low viscosity allowed pouring a fine stream of metal into the mold while letting gases escape. Since zinc reduces the copper ions to metallic copper, brass alloys rarely have gas porosity problems. Moreover, due to its high vapor pressure, zinc may also remove dissolved gases [35].

Since brasses form a complex passive oxide layer of $\mathrm{ZnO}$ and $\mathrm{Cu}_{x} \mathrm{O}_{y}$, the corrosion resistance is excellent [36]. Examples of brasses are: Muntz Metal, invented in 1832 (Patent No. 6347) -60/40 Cu/Zn (60 wt $\% \mathrm{Cu}$ and $40 \mathrm{wt} \%$ Zn) [37]; cartridge brass-70/30 Cu/Zn; Admiralty brass$69 \mathrm{wt} \% \mathrm{Cu}, 30 \mathrm{wt} \% \mathrm{Zn}$, and $1 \mathrm{wt} \% \mathrm{Sn}$; and Naval brass$62 \mathrm{wt} \% \mathrm{Cu}, 37 \mathrm{wt} \% \mathrm{Zn}$, and $1 \mathrm{wt} \%$ Sn [38-40, p. 23].

The concentration of zinc used in brass alloys changed as a result of technological advances. For example, at the beginning of the seventeenth century, organ pipes contained about $26 \mathrm{wt} \% \mathrm{Zn}$. A higher zinc concentration of
$32.5 \mathrm{wt} \% \mathrm{Zn}$ appeared about 1750. Lead concentration in brass also changed during the years; decreasing from 7 to $8 \mathrm{wt} \% \mathrm{~Pb}$ in 1624 to approximately $5 \mathrm{wt} \% \mathrm{~Pb}$ in 1750, and to less than $2 \mathrm{wt} \% \mathrm{~Pb}$ at the end of the eighteenth century [41]. However, in some objects, other considerations also applied; for example, a deliberate addition of lead to a molten metal in order to improve the casting quality.

\section{Experimental Methods and Tests}

For the purpose of this research, six nails (Type A: 135, 155.1, 160.1; Type B: 139, 148.2, 159) from the total of 105, were chosen randomly (Fig. 3; Table 2). They were studied using non-destructive and destructive metallurgical testing (Table 3).

\section{Non-destructive Testing (NDT)}

The NDT comprised the following methods:

(a) Visual examination to detect visible macroscopic level discontinuities and defects that may indicate the manufacturing process.

(b) Density measurements on nails 160.1, 139 and 159, based on Archimedes' principle, to examine the casting quality of the nails, as well as their conservation condition.

(c) X-ray fluorescence (XRF) chemical analysis with a handheld XRF instrument, to detect the general composition of the nails (Table 4). The area examined was $5 \mathrm{~mm}$ in diameter. Light elements, such as oxygen, could not be detected with this XRF machine, due to instrumental limitations.

\section{Metallurgy and Other Destructive Testing and Analysis}

Metallographic examination of the six nails was carried out according to ASTM-E3 Standard. The notation used for the metallographic specimens was: L-CS for longitudinal 
Tables 3 Metallurgical non-destructive and destructive testing

\begin{tabular}{|c|c|c|c|c|c|c|c|}
\hline Nail no. & Description & Dimensions, weight and typology & Lead isotope analysis & $\mathrm{XRF}$ & LM & SEM-EDS & $\mathrm{HV}$ \\
\hline 135 & Type A (long) & + & + & + & + & + & + \\
\hline 155.1 & Type A & + & - & - & + & - & + \\
\hline 160.1 & Type A & + & - & - & + & - & + \\
\hline 139 & Type B (short) & + & + & - & + & + & + \\
\hline 148.2 & Type B & + & - & - & + & - & + \\
\hline 159 & Type B & + & - & + & + & - & + \\
\hline
\end{tabular}

Tables 4 XRF results (L-CS, polished) using handheld XRF instrument

\begin{tabular}{llllll}
\hline Sample & \multicolumn{5}{c}{ Composition weight percentage (wt\%) } \\
\cline { 2 - 6 } & $\mathrm{Cu}$ & $\mathrm{Zn}$ & $\mathrm{Pb}$ & $\mathrm{Sn}$ & $\mathrm{Si}$ \\
\hline 135 (Type A, head) & 62.8 & 35.8 & 0.8 & 0.6 & $\ldots$ \\
135 (A, shank) & 61.3 & 36.2 & 1.1 & 0.6 & 0.8 \\
135 (A, tip) & 62.4 & 35.0 & 0.9 & 0.6 & 1.1 \\
159 (Type B, head) & 64.4 & 33.9 & 0.8 & 0.6 & 0.3 \\
159 (B, shank) & 65.6 & 32.9 & 0.8 & 0.7 & $\ldots$ \\
\hline
\end{tabular}

cross-section and T-CS for transverse cross-section (Fig. 3).

The metallographic samples were mounted in Bakelite. The preparation of the surface consisted of grinding with silicon carbide papers and then polishing with diamond and alumina pastes. The samples were cleaned and then etched with hydrochloric acid in ferric chloride solution $\left(\mathrm{FeCl}_{3}+\mathrm{HCl}+\mathrm{H}_{2} \mathrm{O}\right)$.

The destructive metallurgical examination included the following tests:

(a) After metallographic preparation, nail samples were examined under an optical light microscope (LM) at up to $\times 1000$ magnification to obtain information regarding their microstructure, as well as the presence of micro-defects. Such information is valuable for the understanding of the nail manufacturing process.

(b) Vickers (HV) microindentation hardness measurements of the samples with a $25 \mathrm{gf}$ load (for minimal destruction), and $15 \mathrm{~s}$ dwell time for indents, using ASTM E 384-99 standard for microindentation hardness to determine how the microstructure affected the mechanical properties.

(c) Scanning electron microscopy-energy dispersive spectroscopy (SEM-EDS) local chemical analysis of metallographic samples 135 (Type A) and 139 (Type B) using an environmental SEM to detect local defects, such as interdendritic shrinkage porosity at higher magnification. The samples were characterized in high vacuum mode and a secondary electron (SE) detector. Both SE and backscattered electrons (BSE) modes were used. The local chemical element composition (for example, comparing the compositions inside the dendrites) was analyzed by EDS using a $\mathrm{Si}(\mathrm{Li})$ liquid-cooled $\mathrm{x}$-ray detector.

(d) Lead isotope analysis of nails 135 (Type A) and 139 (Type B) using a multicollector ICP mass spectrometer. The results were subsequently compared with published reference isotope data of potential ore locations in order to identify the possible origin of the raw metals. Details on the column separation method for preparation, the analytical method, the instrument settings, and the errors as applied in the Frankfurt laboratory are described e.g. in Klein et al. [42] and Müller et al. [43].

\section{Hammering Experiment}

An experiment was conducted in order to learn about the hammering effect on the nail shank and head. A 4.2-cmthick pine plank was used to represent the hull planks and an 18.5-cm-thick oak timber represented the frames. Several trials were made: three using modern steel nails, $4.4 \mathrm{~mm}$ in diameter and $10 \mathrm{~cm}$ long; and three using the original brass nails retrieved from the shipwreck: nail number $119,135.9 \mathrm{~mm}$ long and $14.9 \times 14.9 \mathrm{~mm}$ in crosssection; $124.3,131.3 \mathrm{~mm}$ long and $17.5 \times 14.3 \mathrm{~mm}$ in cross-section; and 123, $133 \mathrm{~mm}$ long and $16.2 \times 14.2 \mathrm{~mm}$ in cross-section.

A total of seven steel and three brass nails were used. The steel nails were hammered into the plank alone, into the frame alone, and into the plank and frame. In all these trials, no pre-drilling was done. The brass nails were hammered into the plank alone using a mallet and into the plank and frame after drilling, once using a mallet and once using a hammer. 


\section{Results}

All 105 nails had a protective oxide layer with some minor local corrosion on their external surface, but their core was well preserved. Chemical (XRF and local SEM-EDS) analyses of sampled nails revealed the presence of $\mathrm{Cu}, \mathrm{Zn}$, and some other elements, such as $\mathrm{Pb}, \mathrm{Sn}$ and $\mathrm{Si}$ (Table 4). Below is a description of the analysis results.

\section{Type A (Long Nails)}

Some cast porosity defects, uniform passive oxide layer and minor local corrosion were observed by visual examination on the external surfaces of the nails (Fig. 4). All Type A nail tips examined were intact.

XRF results of nail 135 revealed that it was made of brass with $35.0-36.2 \mathrm{wt} \% \mathrm{Zn}$ and $0.8-1.1 \mathrm{wt} \% \mathrm{~Pb}$, as well as small amounts of $\mathrm{Sn}$ and $\mathrm{Si}$ (Table 4). The measured density of nail 160.1 was $8.1 \mathrm{~g} / \mathrm{cm}^{3}$, and that of nail 155.1 was $8.3 \mathrm{~g} / \mathrm{cm}^{3}$, as expected based on the zinc content.

LM examination of nails 135, 155.1 and 160.1 revealed an as-cast Widmanstätten fine 'basket-weave' parallel lamellae (non-equilibrium) microstructure, which was homogenous in all parts of the nails: head, shank, and tip (Figs. 4, 5). The casting of Type A nails was of good quality, as no cast shrinkage porosity was observed, but only a few bubbles indicating the as-cast entrapped gas porosity (Fig. 4e).

SEM observation of nail 135 revealed parallel lamella colonies of the Widmanstätten microstructure, precipitated at a non-equilibrium cooling rate (Fig. 6a, b). A large volume fraction of $\alpha$-phase was observed, with a small amount of $\beta$-phase at the lamella boundaries. The EDS analysis revealed a higher presence of zinc at the boundaries between the lamellae with compression to the lamellae themselves. For example, in nail 135, there was presence of 34.3-35.8 wt\% $\mathrm{Zn}$ within the lamella plates and 35-39.9 wt\% $\mathrm{Zn}$ in the lamella boundaries (Table 5). Since lead tends to precipitate as islands/inclusions, and since the SEM-EDS analysis focused on the brass matrix, $\mathrm{Pb}$ was not detected by SEM-EDS analysis (in contrast to the XRF results).

The microindentation hardness values of Type A nail heads were lower than those of the nail shanks. For instance, the average value of nail 135 (L-CS) was $96 \pm 9 \mathrm{HV}$ at the head and $127 \pm 14 \mathrm{HV}$ at the shank; and the average microindentation hardness of nail 160.1 was $117 \pm 11 \mathrm{HV}$ at the head and $161 \pm 9 \mathrm{HV}$ at the shank (Table 6). Since it is assumed that Type A nails were used (some of the nails were found inside the wood), it is expected that their head hardness would be greater than the shank hardness due to the hammering process.

\section{Type B (Short Nails)}

According to the visual examination cast porosity, a uniform passive oxide layer and slightly local corrosion were observed; however, the nails were found well preserved. The examination also revealed that the tips of Type $B$ nails seemed to be missing or broken. The broken nail tips were further examined by stereo microscopy, and in some cases, a fractured surface was observed.

XRF results of nail 159 revealed that it was made of brass with $32.9-33.9 \mathrm{wt} \% \mathrm{Zn}$ and up to $0.8 \mathrm{wt} \% \mathrm{~Pb}$, as well as small amounts of other elements, such as $\mathrm{Sn}$ and $\mathrm{Si}$ (Table 4). The measured density of nail 139 was $8.5 \mathrm{~g} / \mathrm{cm}^{3}$, that of nail 148.2 was $8.0 \mathrm{~g} / \mathrm{cm}^{3}$, and that of nail 159 was $8.6 \mathrm{~g} / \mathrm{cm}^{3}$, as expected due to the zinc content, some cast porosity and defects, some slight local corrosion and the presence of oxide layer on the external surface of the nails.

Stereo-microscopy observation of Type B nails (Fig. 7, nail 159, after polishing and etching), revealed large equiaxed $\alpha$-brass grains at the centre of the nails (where the liquid was undercooled), whereas a columnar zone was seen near the mold walls [34, p. 254]. The largest equiaxed $\alpha$-brass (500-2000 $\mu \mathrm{m})$ grains were observed in all of the nail heads, while oriented elongated $\alpha$-brass grains were observed at the external surface of the shanks.

LM examination of nails 139 (Fig. 8), 148.2 (Fig. 9a-d) and 159 (Fig. 10) revealed that the as-cast large equiaxed $\alpha$-brass grains included dendrites in all nail parts. SEM examination (after etching) revealed $\alpha$-brass cored dendrites with some interdendritic shrinkage porosity cast defects (Fig. 6c-f). The EDS analysis of nail 139 revealed the presence of 31.6-34.6 wt\% $\mathrm{Zn}$ inside the dendrites, whereas the dendrite boundaries were rich in $\mathrm{Zn}$ 35.7-36.7 wt\%, as well as Sn and Fe impurities (Table 5). The difference in composition between the dendrite arms at the exterior part and the inner part probably resulted from the coring effect due to a non-equilibrium cooling rate.

The microindentation hardness values of Type $B$ nail heads were lower than in the nail shank and tip. For example, the average microindentation hardness of nail 159 was $90 \pm 9 \mathrm{HV}$ at the head, $117 \pm 9 \mathrm{HV}$ at the shank near the head, and $112 \pm 6 \mathrm{HV}$ at the shank near the tip (Table 6). Some of the tips were broken or actually missing, and the measured hardness values were in fact of the shank near the tip rather than the tip itself. Since the nails were found with their tips broken, it is most likely that they had been used.

\section{The Hammering Experiment}

The steel nails were easily hammered into the pine plank. When hammered into the oak frame, the steel nails penetrated to a depth of $3.8 \mathrm{~cm}$ and then bent. However, 
Fig. 4 Nail 135 (Type A) metallographic examination showing Widmanstätten lamellae (L-CS, etched): (a) head; (b) head $(\times 500$ magnification); (c) shank; (d) shank $(\times 500)$; (e) tip showing an entrapped gas bubble (dark circle); (f) tip $(\times 500)$

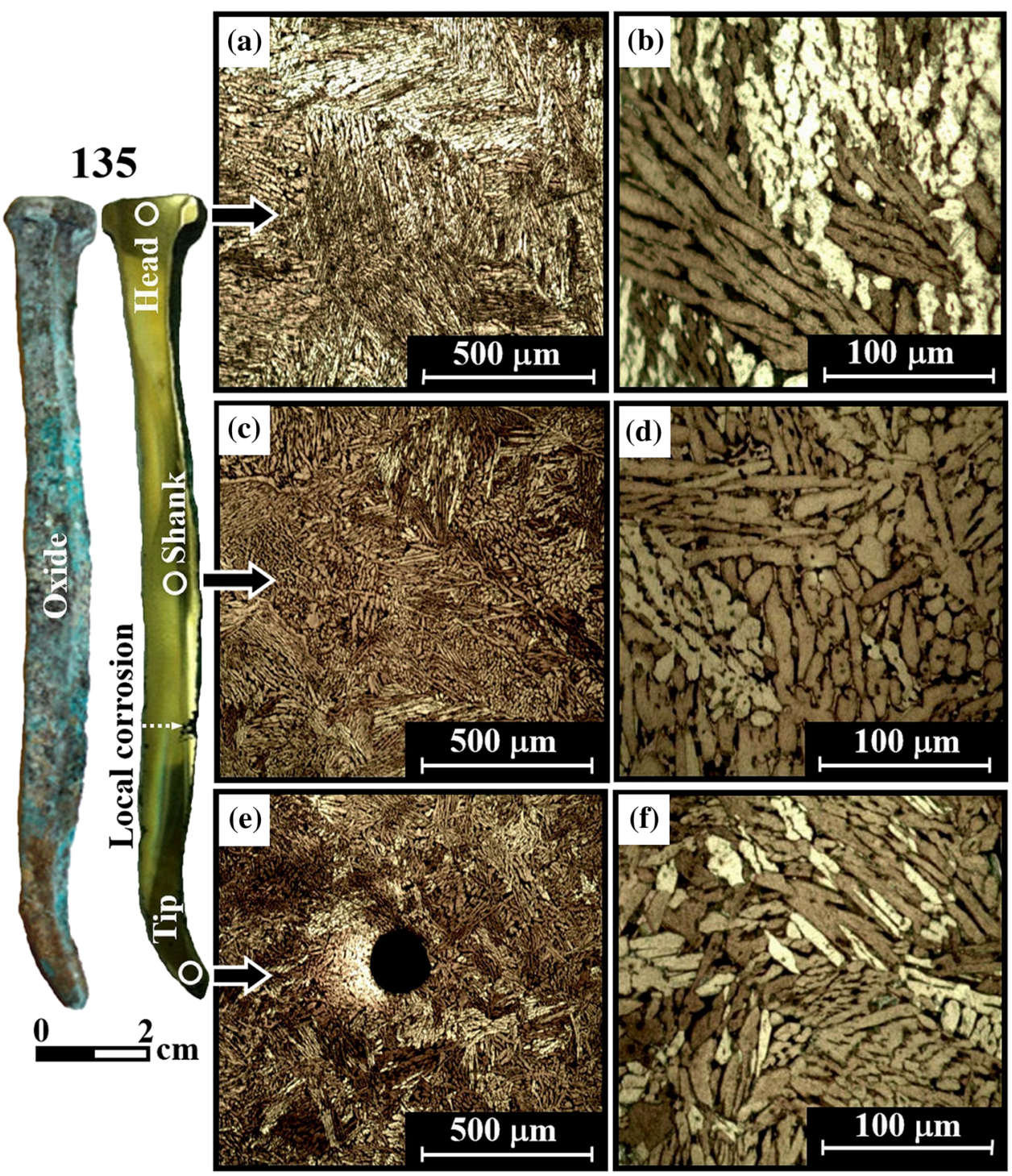

when hammered into the plank and frame, they reached a depth of $6.7-8.5 \mathrm{~cm}$ before bending. A single nail entered the plank and frame to its entire $10 \mathrm{~cm}$ length.

Brass nail 119 was hammered into the pine plank alone using a mallet. It was driven parallel to the tree grain with hardly any effort (Fig. 11a), but was broken into four pieces-a demonstration of its production by casting (Fig. 11b). In the second trial, nail 124.3 was hammered into the plank and frame with a mallet, perpendicular to the plank grain. A 10-mm-diameter hole was pre-drilled through the plank to a depth of $7.5 \mathrm{~cm}$ into the frame. The nail was easily driven into the wood intact, and held well. No impression was left on the upper surface of the head (Fig. 11c, d).

The last trial was similar to the second, including predrilling, except that nail 123 was hammered using an $800 \mathrm{~g}$ hammer. The nail was easily driven into the wood intact and held well. Although a metal hammer was used, no impression was identified on the nail head.

The trials demonstrated that pre-drilling in the hull planks and the framing timbers was essential. When nail heads were examined after hammering, no significant changes were detected.

\section{Discussion}

Initially, the Akko Tower Wreck nails were divided into two groups based on geometrical considerations such as length and head shape. Nails belonging to Type A are characterized by long shanks (although some were broken) and Type B nails are characterized by short shanks.

In addition to the geometrical differences, chemical analyses of the nails revealed that although Types A and B 
Fig. 5 Metallographic examination of Type A nails ( $\times 50$ magnification, T-CS, etched) showing Widmanstätten lamellae microstructure: (a) 155.1 nail head and nail 160.1; (b) head; (c) shank; (d) tip

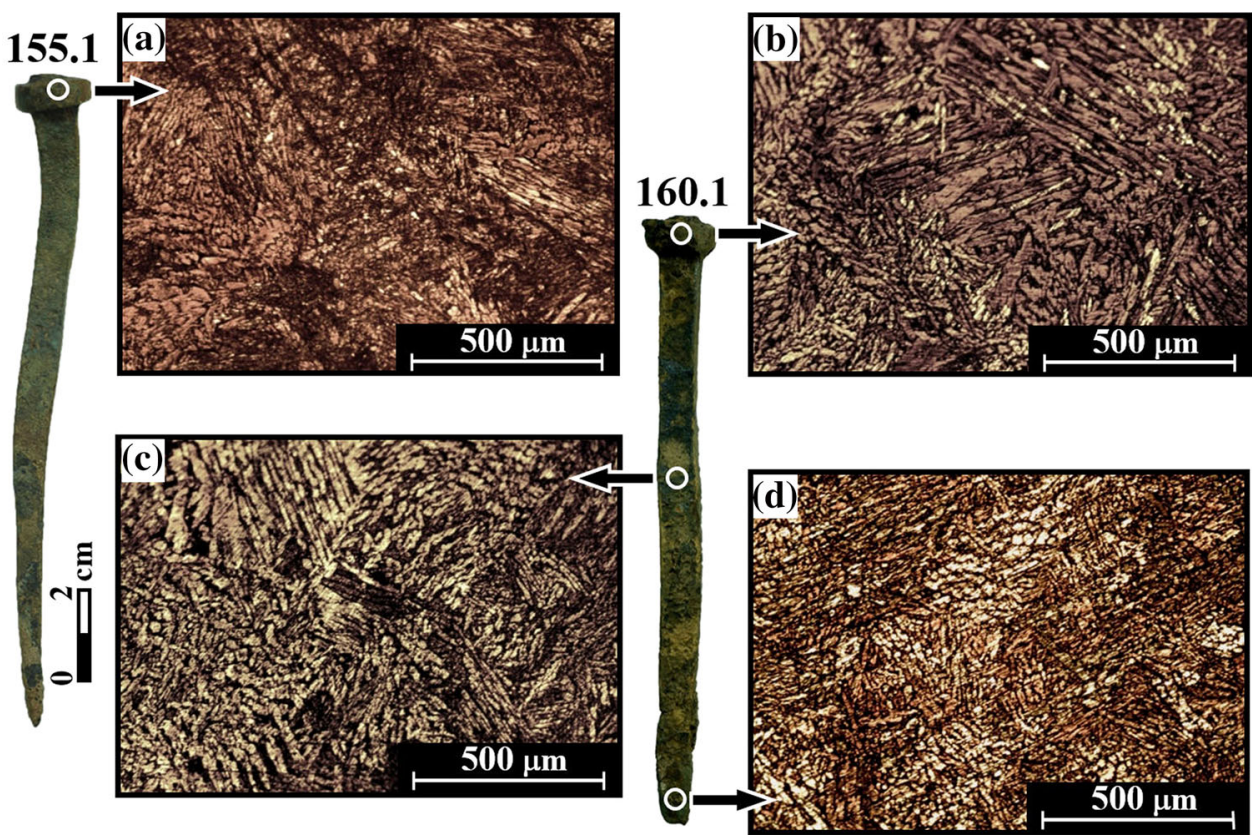

were made of brass, their compositions were different, thus supporting the typological grouping. The classification was further confirmed by the different microstructure of nails in each group.

The average density of Type A nails was $8.2 \mathrm{~g} / \mathrm{cm}^{3}$ and the average density of Type B nails was $8.4 \mathrm{~g} / \mathrm{cm}^{3}$. Such densities indicate the good quality of the cast brass, as well as on the good state of preservation of the nails. In comparison, the density of twenty-first century cartridge brass is $8.5 \mathrm{~g} / \mathrm{cm}^{3}$ [44], and the density of modern naval brass that was corroded for 12 weeks was $8.2 \mathrm{~g} / \mathrm{cm}^{3}$ [45].

The nails contained more than $32 \mathrm{wt} \% \mathrm{Zn}$ : Type A contained 34.9-36.0 wt $\mathrm{Zn}$ and Type B contained 32.8-33.8 wt\% Zn (Table 4). The difference in composition supports the preliminary division of the nails into two groups. In addition, small amounts of $\mathrm{Pb}$ (about $1 \mathrm{wt} \%$ ), Sn (about $1 \mathrm{wt} \%$ ) and $\mathrm{Si}$ (up to $1 \mathrm{wt} \%$ ), were also found in all nail types (Table 4). The Si source (concentration of up to $1.1 \mathrm{wt} \%$ ) is unknown, and could have resulted from: (1) the use of a sand mold, (2) the presence of inclusions found in the brass [46, 47], or (3) the presence of sea sand. The lead may have originated from the $\mathrm{Zn}$ ore. Such $\mathrm{Pb}$ presence is common in post-medieval brasses and bronzes [17, 48]. Tin contents below $2 \mathrm{wt} \%$ might be found in $\mathrm{Cu}$-based objects due to bronze recycling and/or to the use of Sn-containing ores [49].

Based on their microstructures, microindentation hardness, and the presence of some casting defects, it is clear that all the brass nails were manufactured by sand or metal mold casting. However, the presence of silicon in the nails indicates that they were most probably manufactured by sand casting, with no further cold or hot working. This is also reinforced by the fact that nail 119 broke into pieces during the hammering experiment, probably because the as-cast brass was brittle. For both Type A and B nails, the head microindentation hardness values were lower than the shank values (Table 6). These values are as expected, since both Widmanstätten lamellae (Type A) and brass grains (Type B) were larger at the nail heads (the last parts to solidify). Nevertheless, this behavior may also be explained by a non-equilibrium cooling rate characterized by dendritic segregation (coring effect), which causes a compositional gradient, as well as a large distribution of the hardness values in the cast object [27, pp. 5, 103, 139]. This trend may also indicate the possible use of an auger to drill holes through the plank and into the framing timber, as was demonstrated in the hammering trials. It took skill and patience to insert the nails and hammer them into place.

As some of the nails were found in situ (inside the wood), and those that were detached were in the wrecksite, in close proximity to the hull remains, it is logical to postulate that they were also used. In such a case the local deformation increased their hardness values, and may explain the distribution of their hardness results. However, the differences in cooling rates during the casting process, as well as differences in composition, may contribute to the hardness variations [22]. Due to the good preservation of the nails, it is unreasonable that the work-hardened layer at their head was destroyed as a result of corrosion attack.

Metallographic examination of Type A nails revealed an as-cast Widmanstätten lamellae microstructure. During solidification of Type A nails, a two-phase alloy 
Fig. 6 Brass nail examination (SEM, etched); Nail 135 (Type A): (a) Widmanstätten lamellae (SE) and (b) Widmanstätten lamellae (BSE); Nail 139 (Type B): (c) $\alpha$-brass dendritic microstructure (SE); (d) higher magnification of the dendrites (SE); (e) $\alpha$-brass with interdendritic shrinkage porosity (dark areas, BSE); (f) higher magnification of the shrinkage porosity (dark areas, $\mathrm{SE})$
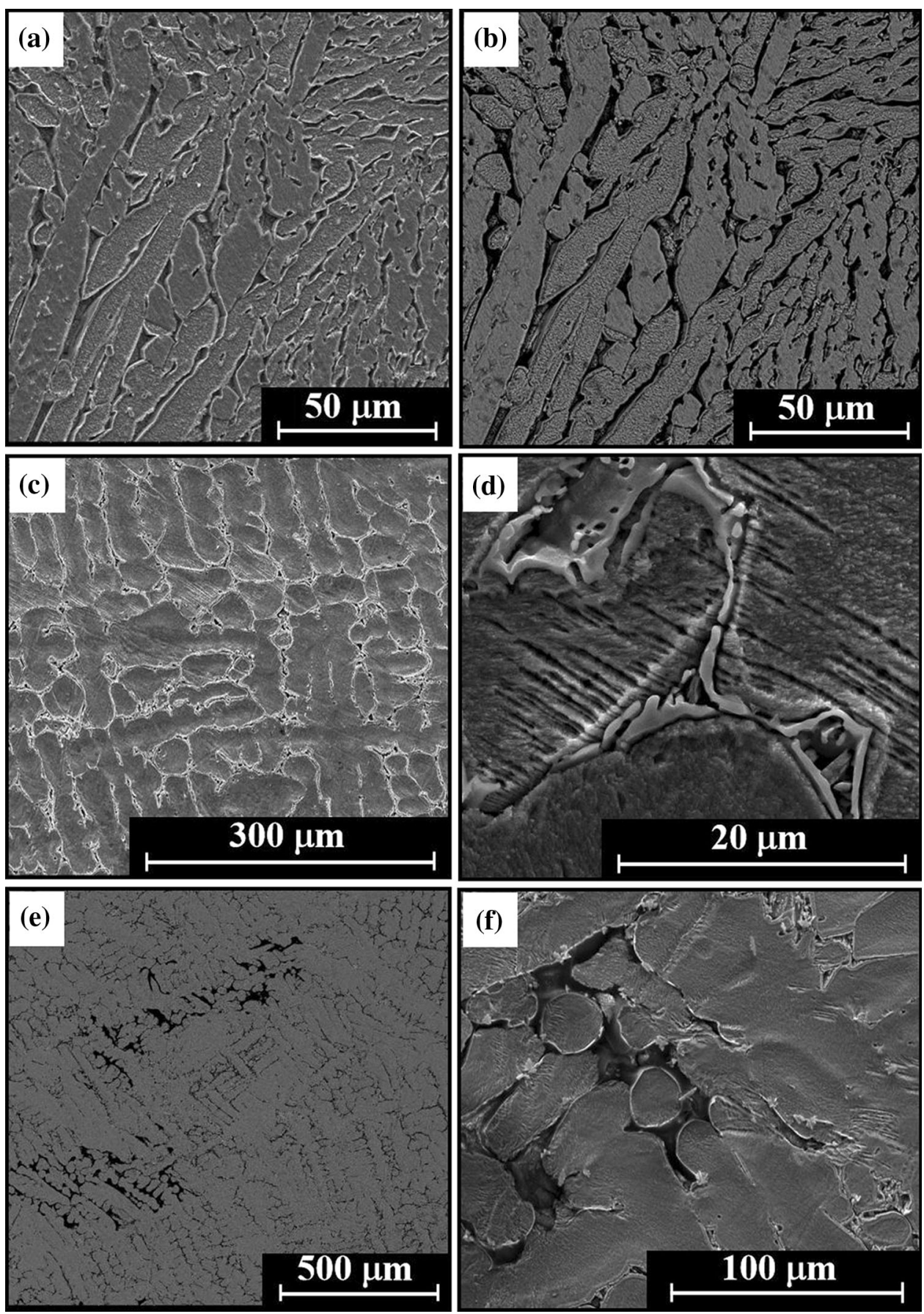

( $\alpha-\beta$-brass) was obtained, demonstrating a Widmanstätten lamellae microstructure, typical of a fast cooling rate. When solidification begins, $\alpha$-phase precipitates first, forming Widmanstätten lamellae (bright area in LM) with long preferred growth directions, followed by $\beta$-phase precipitation (dark areas) at the Widmanstätten lamellae boundaries [50-55]. The $\alpha$ - $\beta$-brass (with more than $34 \mathrm{wt} \% \mathrm{Zn}$ ) alloy is harder and stronger than $\alpha$-brass, but with less ductility and less corrosion resistance.
Examination of Type B nails revealed the as-cast equiaxed $\alpha$-brass cored grains with dendrites in all nail parts, with the largest equiaxed grain presence in the nail heads, whereas elongated $\alpha$-brass grains were observed at the external surface of the shanks. The large grains indicate that the last metal to solidify was in the nail heads. Although the presence of silicon probably indicates that the nails were manufactured by sand casting, the oriented elongated $\alpha$-brass grains suggest that the mold was made of 
Tables 5 SEM-EDS results (L-CS, polished, and etched), using ESEM (values in wt\%)

\begin{tabular}{lllll}
\hline Compositions (wt\%) & $\mathrm{Cu}$ & $\mathrm{Zn}$ & $\mathrm{Sn}$ & $\mathrm{Fe}$ \\
\hline 135 (Type A, head, area 1), lamellae & 65.7 & 34.3 & $\ldots$ & $\ldots$ \\
135 (A, head, area 1), lamellae boundary & 63.9 & 35.0 & 1.1 & $\ldots$ \\
135 (A, head, area 2), lamellae & 64.2 & 35.8 & $\ldots$ & $\ldots$ \\
135 (A, head, area 2), lamellae boundary & 56.8 & 39.9 & 2.2 & 1.1 \\
139 (Type B, head, area 1), dendrite & 67.7 & 32.3 & $\ldots$ & $\ldots$ \\
139 (B, head, area 1), dendrite boundary & 58.6 & 35.9 & 5.5 & $\ldots$ \\
139 (B, head, area 2), dendrite & 65.4 & 34.6 & $\ldots$ & $\ldots$ \\
139 (B, head, area 2), dendrite boundary & 57.3 & 35.7 & 5.8 & 1.2 \\
139 (B, shank, area 3), dendrite & 68.4 & 31.6 & $\ldots$ & $\ldots$ \\
139 (B, shank, area 3), dendrite boundary & 59.2 & 35.7 & 5.1 & $\ldots$ \\
139 (B, area 4), dendrite & 66.5 & 33.5 & $\ldots$ & $\ldots$ \\
139 (B, area 4), dendrite boundary & 54.9 & 36.7 & 8.4 & $\ldots$ \\
\hline
\end{tabular}

metal. In such a case, the presence of silicon results from the presence of inclusions in the brass or as a result of the presence of sea sand.

All sampled nails were analyzed in cross-section, although the thickness of the metal did not display any recrystallized twinned grains; meaning that all brass nails were used in the cast state, with no further cold- or hotworking processes. Due to the $\mathrm{Zn}$ content (Table 4) being lower than the solubility limit in $\mathrm{Cu}$ for most of the nails (about $35 \mathrm{wt} \% \mathrm{Zn}$ at room temperature), the $\mathrm{Cu}$-rich heavily cored dendritic matrix displays a single-phase microstructure. Some shrinkage cavities were observed in the interdendritic spaces (Fig. 6e, f). The nails were probably air-cooled from the casting temperature. The relatively fast cooling rate of Type A nails generated a Widmanstätten lamellae microstructure. The cored dendritic matrix displayed a rich concentration of $\mathrm{Zn}$ at the dendrite bound-
Tables 6 HV microindentation hardness test results ( $25 \mathrm{~g}$ load)

\begin{tabular}{lccrr}
\hline Nail sample & \multicolumn{2}{l}{ Vickers microhardness (HV) } & \\
\cline { 2 - 5 } & Minimum & Maximum & Average & SD \\
\hline 135 (Type A, head, L-CS) & 84 & 112 & 96 & 9 \\
135 (A, shank near head, T-CS) & 87 & 121 & 103 & 12 \\
135 (A, shank, L-CS) & 106 & 144 & 127 & 14 \\
135 (A, tip, L-CS) & 97 & 120 & 110 & 8 \\
155.1 (Type A, shank near tip, L-CS) & 144 & 168 & 152 & 11 \\
160.1 (Type A, head, L-CS) & 103 & 132 & 117 & 11 \\
160.1 (A, head, T-CS) & 131 & 169 & 144 & 16 \\
160.1 (A, shank, L-CS) & 148 & 173 & 161 & 9 \\
160.1 (A, shank, T-CS) & 125 & 163 & 148 & 14 \\
160.1 (A, tip, L-CS) & 114 & 137 & 125 & 9 \\
139 (Type B, shank near tip, L-CS) & 133 & 169 & 153 & 9 \\
159 (Type B, head, L-CS) & 82 & 107 & 90 & 9 \\
159 (B, shank near head, L-CS) & 102 & 131 & 117 & 6 \\
159 (B, shank near tip, L-CS) & 104 & 120 & 112 & 7 \\
148.2 (Type B, shank near tip, L-CS) & 137 & 154 & 147 & \\
\hline
\end{tabular}

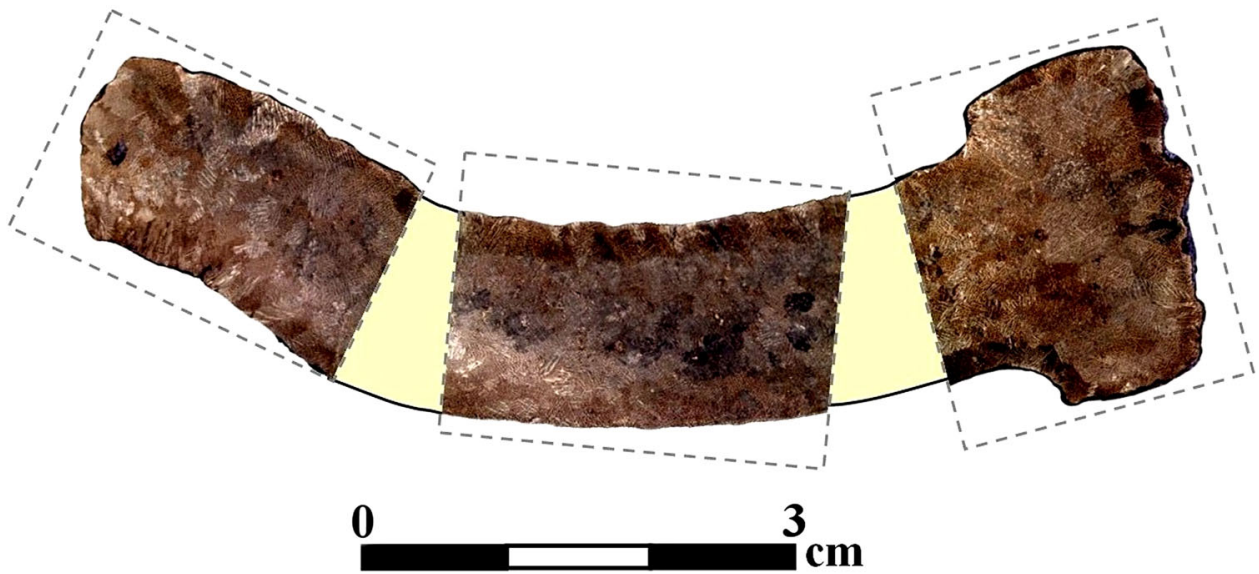

cm
Fig. 7 Nail 159 (Type B) macro-scale of the head (stereo microscopy), shank and tip showing large equiaxed $\alpha$-brass grains; and dendritic microstructure inside the cored grains 
Fig. 8 Nail 139 (Type B) (LM, T-CS, etched) showing large equiaxed $\alpha$-brass grains containing dendritic microstructure: (a) head; (b) head ( $\times 500$ magnification); (c) shank; (d) shank $(\times 500)$; (e) shank/tip; and (f) shank/tip $(\times 500)$

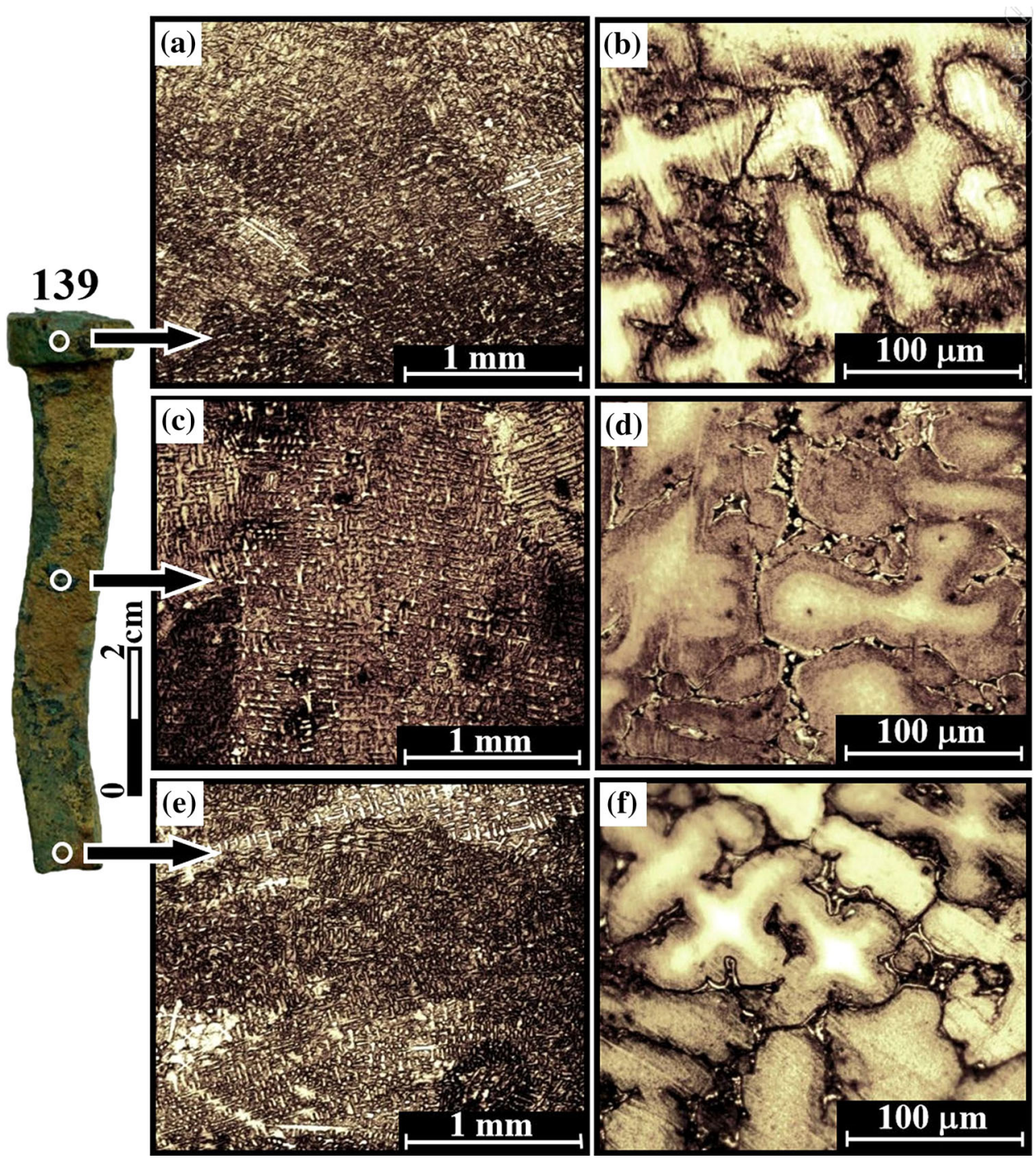

aries, as expected from the non-equilibrium solid microstructures that form when the $\mathrm{Cu}-\mathrm{Zn}$ liquid brass alloy cools.

The different amounts of zinc in the two nail Types (A and B) influenced their microstructure. This indicates two different working processes, and possibly that the nails were manufactured in two different workshops. Perhaps the original intention was that each group of nails would fasten different components during construction; however, ultimately we have evidence of Type A and Type B nails being used on the same hull planks.

Brass produced prior to the middle of the nineteenth century contained relatively high amounts of impurities [56]. Since the zinc concentration in all nails was greater than $32 \mathrm{wt} \%$, it is suggested that the nails were made of speltered brass. Thus, the earliest date of manufacture was in the early nineteenth century, when the phasing out of the cementation process began.
Muntz metal (60/40), which is considered to be the classical formulation of brass [57, p. 17], can perhaps help in pointing to a time frame in which the manufacturing of the nails took place. All nails - and especially nails for ship construction-require strength, some elasticity and corrosion resistance in sea water, advantages which the properties of the Muntz metal provide. Therefore, following the invention of Muntz metal, there was a gradual conversion to its use [58], and by 1840 Muntz metal was commercially available in significant quantities $[57$, p. 17, 59, p. 32]. It seems likely that the best quality brass available would have been used; however, the Akko Tower Wreck nails were not made of Muntz metal. Thus, considering the chemical analysis results, the nails were probably made before the $1840 \mathrm{~s}$.

The Akko Tower Wreck nails were compared to other brass objects from marine and terrestrial environments in order to find similarities in their zinc and lead quantities 
Fig. 9 Nail 148.2 (Type B) (LM, after etching) showing large equiaxed $\alpha$-brass grains with dendritics: (a) head (TCS); (b) head $(\times 100$ magnification); (c) shank/tip (L-CS); (d) shank/tip $(\times 100)$
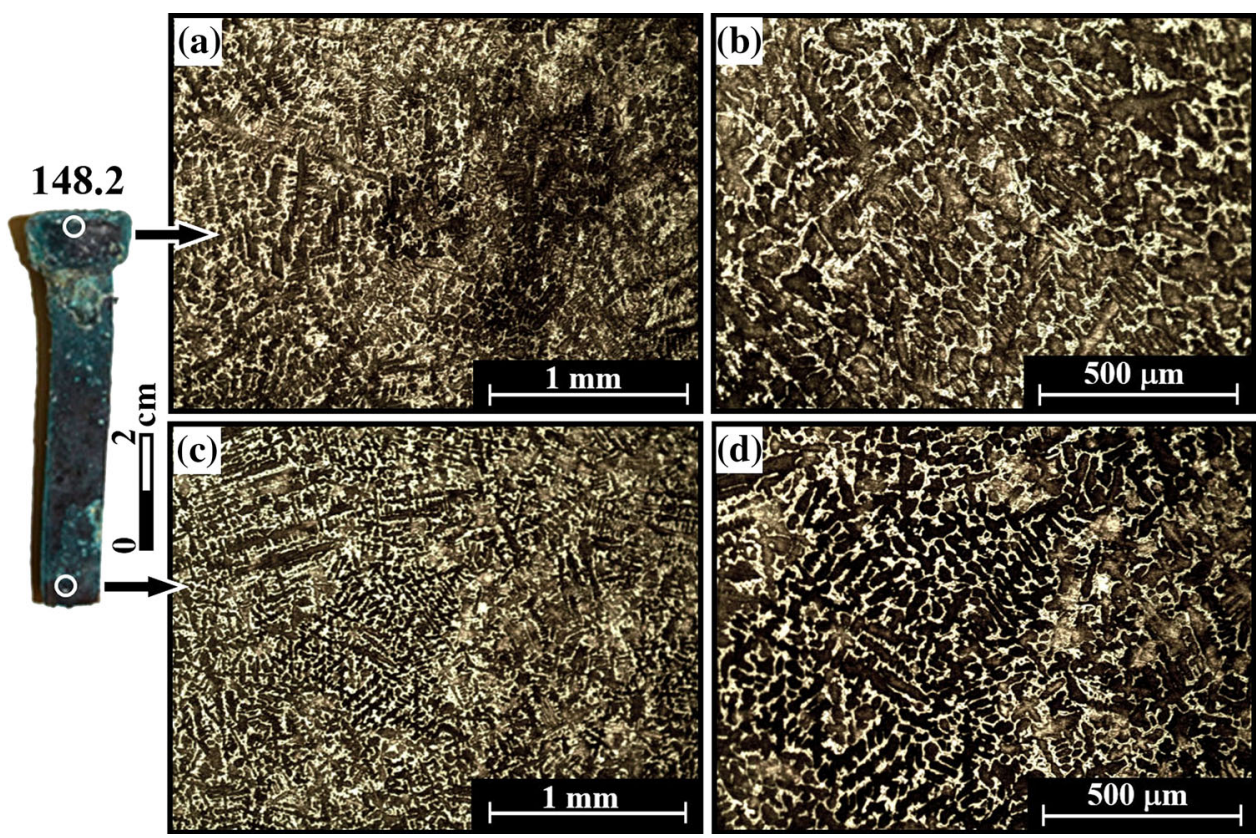

Fig. 10 Nail 159 (Type B) showing large equiaxed $\alpha$-brass grains $(500-2000 \mu \mathrm{m})$

containing dendrites, with arms rich with copper (LM, T-CS, etched): (a) head; (b) head ( $\times 100$ magnification); (c) shank; (d) shank $(\times 100)$; (e) shank/tip; (f) shank/tip $(\times 100)$
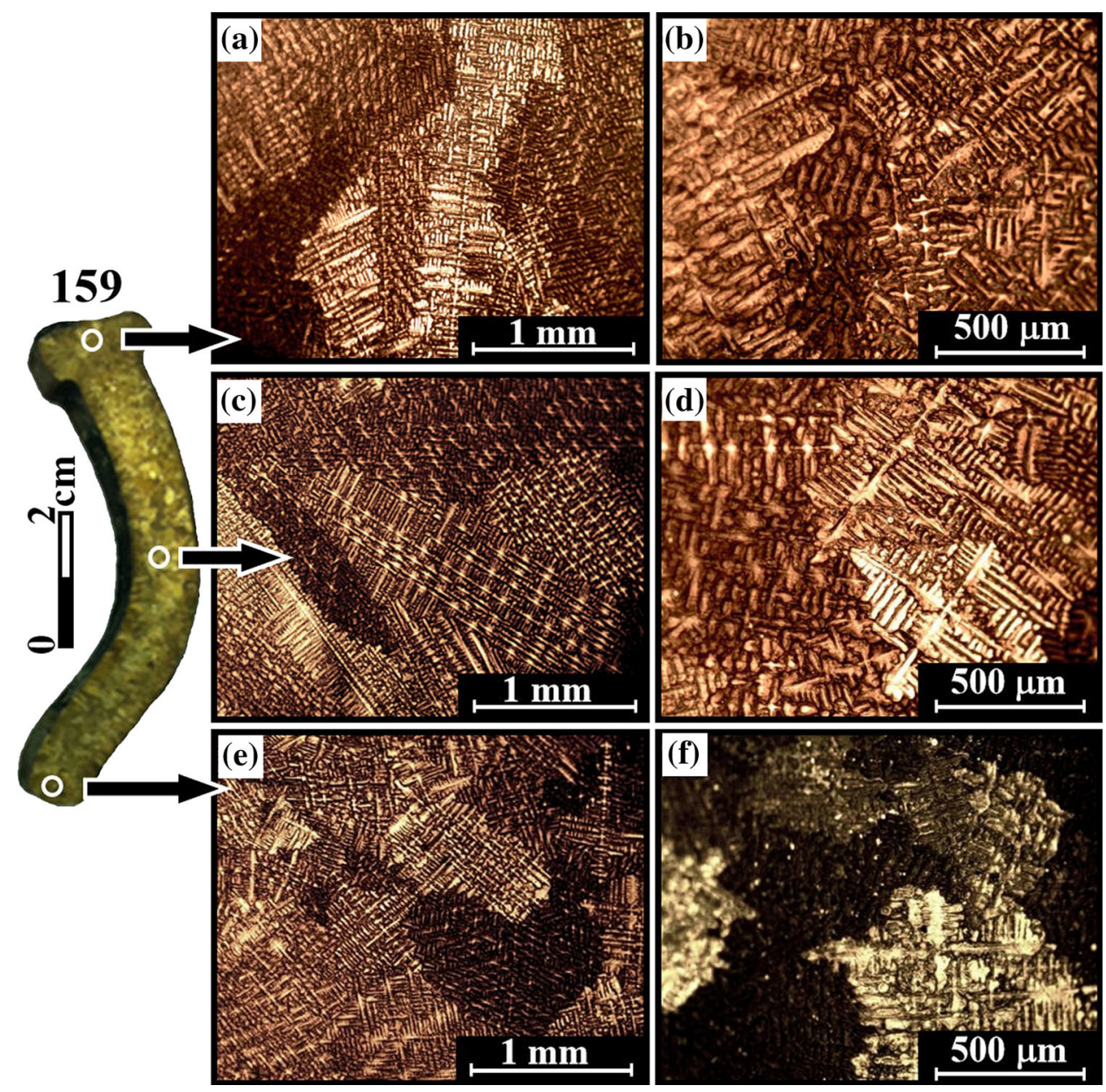
Fig. 11 The hammering experiment: nail 119: (a) at the beginning of being hammered to the plank; and (b) broken into four pieces; nail 124.3: the head before (c) and after

(d) hammering with a mallet

(Photos: N. Cvikel)

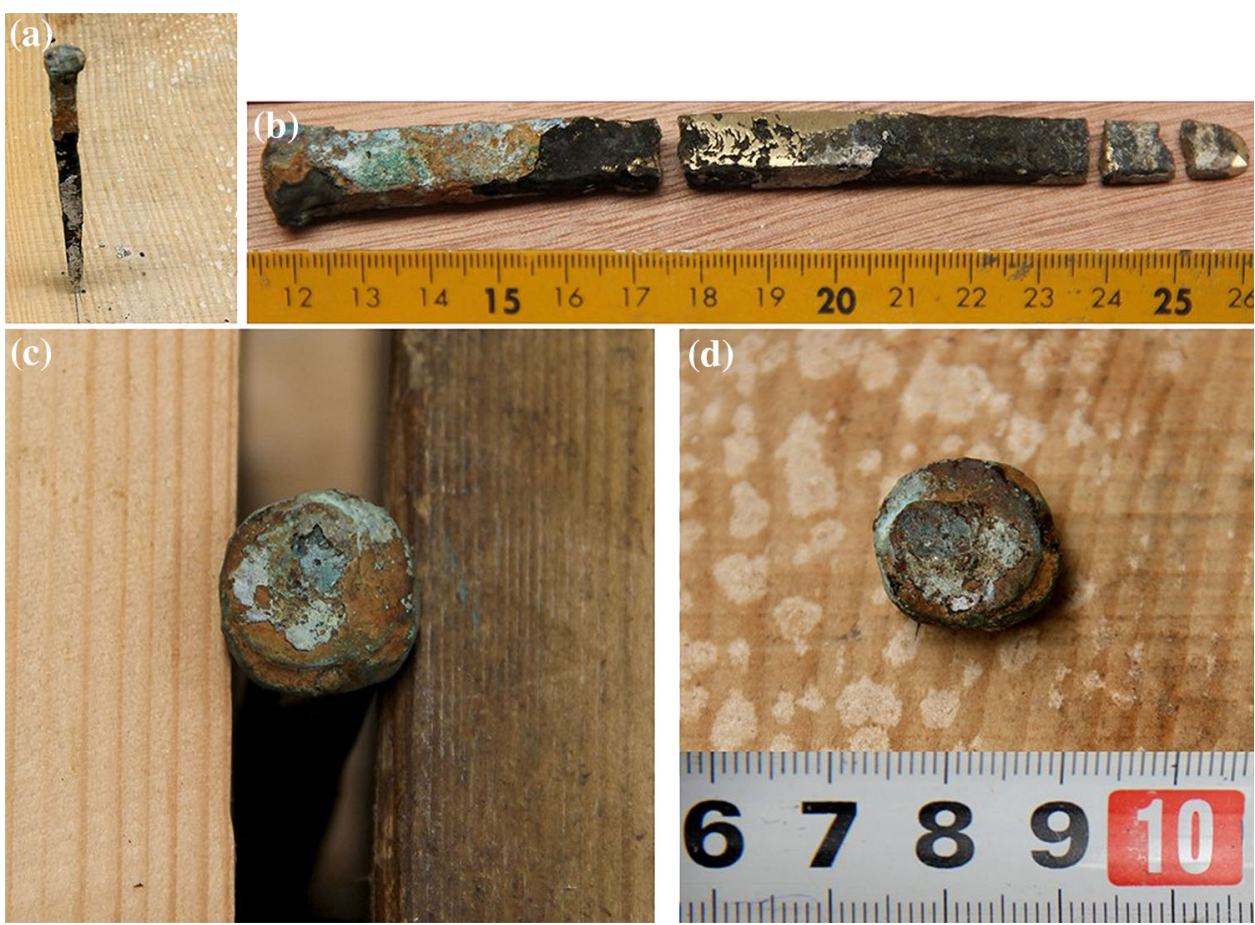

Tables 7 Zinc and lead concentrations (wt $\%$ ) in various brass objects examined in the literature

\begin{tabular}{|c|c|c|c|c|c|}
\hline Artefact & Origin & Year & $\mathrm{Zn}(\mathrm{wt} \%)$ & $\mathrm{Pb}(\mathrm{wt} \%)$ & Reference \\
\hline $\begin{array}{l}\text { Tongues and shallots } \\
\text { of organ pipes }\end{array}$ & European countries & $1624-1790$ & $\sim 26$ & $\begin{array}{l}\text { From } 7-8 \text { in } \\
1624 \text { to } 2 \text { in } 1750\end{array}$ & {$[41$, pp. 252-253] } \\
\hline $\begin{array}{l}\text { Tongue and shallots } \\
\text { of organ pipes }\end{array}$ & European countries & $1750-1790$ & $\sim 32.5$ & $0-2$ & {$[41$, pp. 252-253] } \\
\hline $\begin{array}{l}\text { Tongues and shallots } \\
\text { of organ pipes }\end{array}$ & European countries & $\begin{array}{l}\text { End of } 18 \text { th century- } \\
\text { present day }\end{array}$ & $\begin{array}{l}\text { Higher level } \\
\text { of } 32.5\end{array}$ & After 1820: no lead & {$[41$, pp. $252-253]$} \\
\hline Nail from Rapid shipwreck & USA & 1807 & 26.4 & 1.9 & {$[57$, pp. 16-17] } \\
\hline Bolt from Gem shipwreck & UK & 1835 & 32.4 & 1.2 & {$[57$, pp. 16-17] } \\
\hline $\begin{array}{l}\text { Bolts and a Nail from Flower } \\
\text { of Ugie shipwreck }\end{array}$ & UK & 1838 & $30.5-33.7$ & $0.3-1.0$ & {$[59$, p. 103$]$} \\
\hline Ludwig Leichhardt plate & Australia & 1848 & 36.7 & 1.5 & {$[57$, p. 17] } \\
\hline Bolt from Mary Hamilton shipwreck & Australia & 1857 & 31.5 & 0.7 & {$[57$, p. 17] } \\
\hline Busts of Pope Paul III Farnese & Italy & Nineteenth century & $23-36$ & $2-3$ & {$[26$, p. 15$]$} \\
\hline
\end{tabular}

(Table 7). Firstly, a brass nail with $26.4 \mathrm{wt} \% \mathrm{Zn}$ from the Rapid shipwreck can serve as an example of brass manufactured using the cementation process in the early nineteenth century [57, pp. 16-17]. Secondly, a brass bolt that was recovered from the 1835 Gem shipwreck had a zinc content of $32.4 \mathrm{wt} \%$ [57, pp. 16-17]-similar to the amount of zinc in Type B nails. Another shipwreck from the same period is the Flower of Ugie. Four brass bolts and a brass nail also exhibited similar zinc amounts to Type B nails-30.5-33.74 wt\% [59, p. 103]. Similarly, a brass bolt retrieved from the 1857 Mary Hamilton showed a composition of $31.5 \mathrm{wt} \% \mathrm{Zn}$ [57, p. 17]. This demonstrates that even after the introduction of Muntz metal in 1832, not all ships with brass fasteners used this copper-zinc alloy. Regarding the tongues and shallots of organ pipes, Baretzky et al. [41] stated that both concentrations of zinc (26 and $\sim 32.5 \mathrm{wt} \% \mathrm{Zn}$ ) coexisted from 1750 until the end of the eighteenth century-40 years. This is true for the brass used in the organ pipes, but it is not certain for all brassware, and more research is required on this topic.

The results of the amounts of lead in the brass used for the Akko Tower Wreck nails can provide additional information on their manufacturing date; therefore, providing a clue to the date of the ship (Table 7). According to 
Fig. 12 Lead isotope ratio of nails 135 (Type A), and 139 (Type B), compared with published reference data for ores of relevant ore deposits: (a) ratios of ${ }^{207} \mathrm{~Pb} /{ }^{206} \mathrm{~Pb}$ vs. ${ }^{208} \mathrm{~Pb} /{ }^{206} \mathrm{~Pb}$, and (b) ratios of ${ }^{207} \mathrm{~Pb} /{ }^{206} \mathrm{~Pb}$ vs. ${ }^{206} \mathrm{~Pb} /{ }^{204} \mathrm{~Pb}$
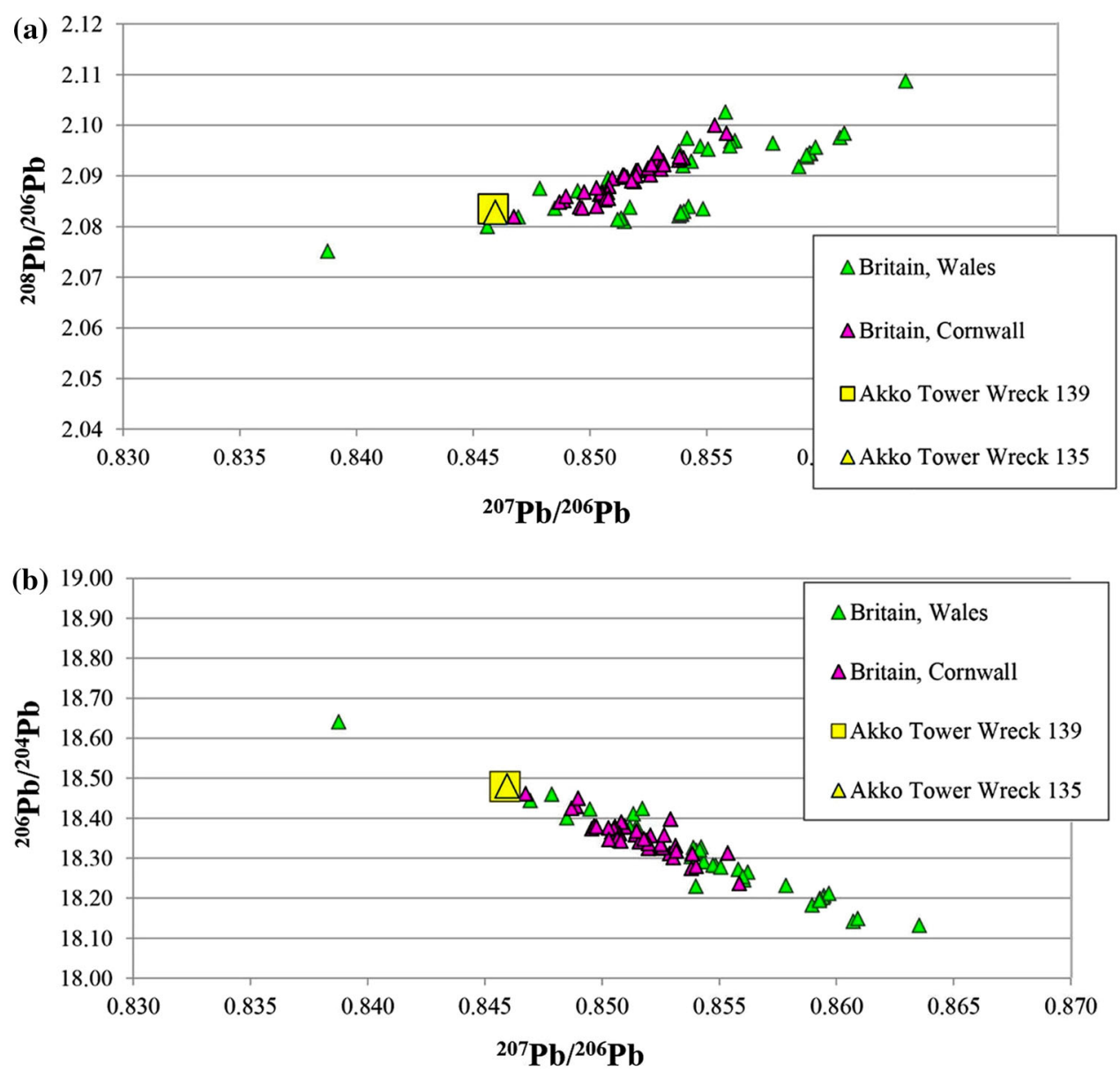

Baretzky et al. [41], the concentration of lead decreased from 7 to $8 \mathrm{wt} \%$ in 1624 to $2 \mathrm{wt} \%$ by the middle of the eighteenth century. Baretzky et al. [41] also indicated that by the end of the eighteenth century the amount of lead in brass was less than $2 \mathrm{wt} \%$, and after 1820 no lead was found in the tongues and shallots of organ pipes. However, although showing a decrease in the amount of lead as the years progress-in brass objects retrieved from a marine environment, small amounts of lead were still found after 1820 [57, p. 17]. MacLeod explained this by saying that "small amounts of lead were a typical impurity in nineteenth century brass" [57, p. 4]. Another example of lead found in brass objects manufactured probably after 1820 are brass busts with $2-3 \mathrm{wt} \% \mathrm{~Pb}$ [31]. All nails had $0.5-1.1 \mathrm{wt} \% \mathrm{~Pb}$. Based on the amount of lead in the Akko Tower Wreck's brass nails, it is suggested that they were manufactured in the first half of the nineteenth century.

In general, the lead isotope interpretation of alloys is not simple, because the lead isotope signature of the alloy is always a mixture of signatures of the alloying metals (and consequently of their ores); in this case a mixture of copper ores and lead-zinc ores. The interpretation of the lead isotope data is even more difficult, whenever it is not absolutely clear whether primary zinc-bearing sulfide ore (predominantly lead-zinc ores) or secondary oxidized zinc ore (e.g. calamine) was smelted. If primary sulfide ore was smelted, both copper and zinc are lead-containing and therefore contribute their lead isotope signature: with a ratio of roughly $70 / 30 \mathrm{Cu} / \mathrm{Zn}$ the signature is almost balanced. If secondary oxidized zinc ore is used, the lead content of the zinc ore is much poorer than that of the copper alloying component, and the signature of the copper ore consequently dominates. Therefore, lead isotope analysis of the three nails is not definite proof for the origin of the copper and zinc ores.

However, an attempt to identify the probable origin of the ores was made. In addition to the nail samples, an international standard was measured to monitor the accuracy of the analyses, and a blind was measured to prove the purity required of the chemicals used (acids, resin). Lead isotope signatures of nails 135 and 139 are almost identical (Fig. 12; Table 8), and despite the compositional differences, this indicates that there was a common metal source for the materials. Various mining areas from Europe were tested for matching with the lead isotope signature of the brass nails, one of them being the copper and lead-zinc 


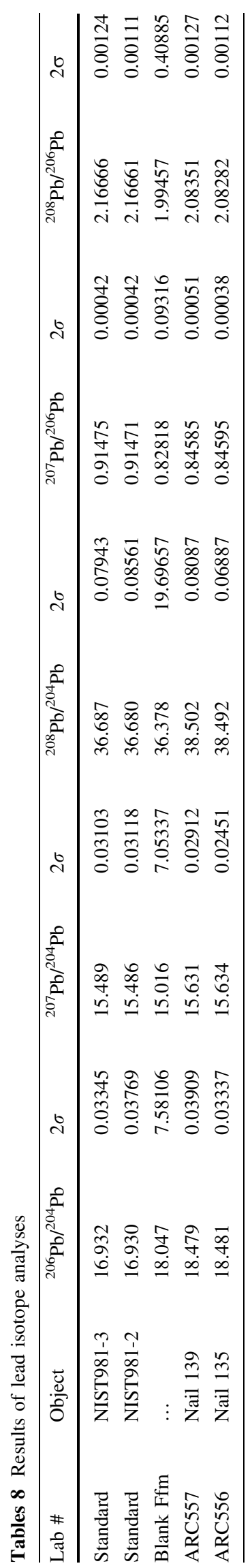

ores from Great Britain [60]. Most of the published lead isotope data rely on lead ores rather than copper ores, but this only reflects the present state of research. During the eighteenth and early nineteenth centuries, Great Britain led in copper production. Copper was produced in Wales and Cornwall, where major mines and coalfields were situated. Brass was also produced in large amounts [61, 62]. There are no absolutely certain matches between European ores from France [63-65], Iberia [66-74] and the Alps [75-78], and the nails, but there is some indication that the British ores have to be taken into account. The lead isotope signatures of nails 135 and 139 do match the British lead isotope ore field at least marginally, and their origin in British ores (from Wales or Cornwall) is a reasonable conclusion.

Despite compositional differences, the high zinc concentrations in the alloys, and the ores used in two of the nails originating from the same source indicate that the metal used for manufacturing the nails was most likely new and not recycled. This also emphasizes that the two nail Types (A and B) were probably manufactured in two different workshops, or for different purposes on the ship. The fact that the ore most probably originated in Great Britain also raises the question about the Akko Tower Wreck's origin. After two underwater excavation seasons, it seems that the Akko Tower Wreck hull construction does not follow typical British ship construction traditions of this period. Perhaps the brass nails were manufactured from raw material that was imported from Great Britain. Another possibility is that the nails were made in Great Britain and shipped ready to use to continental Europe. Further research is still needed to definitely establish the origin of the ship.

As discussed previously, the change in brass composition in the eighteenth and nineteenth centuries was not continuous, and its development and use was not necessarily linear. This archaeometallurgical research contributes additional valuable information to the history of metallurgy, and sheds light on the possible manufacturing date of the Akko Tower Wreck's brass nails.

The current results also support Steffy's assumptions that the origin of the ship is Western Europe, and she can be dated to the nineteenth century.

\section{Conclusions}

During the eighteenth-nineteenth centuries, major changes in brass manufacturing technologies took place, and as a result new brass alloys with higher zinc composition and improved mechanical properties were invented. However, the current research demonstrates that the changes in brass alloy composition were evolutionary non-linear processes 
that were dependent on various engineering considerations, such as the functionality of the product combined with the customer's demands, as well as different manufacturing processes and factories, cost constraints, and the use of different standards.

The archaeometallurgical analyses provided new information on the manufacturing processes, date, and possible origin of the raw material of the nails. All the nails examined were made by casting; however, slight differences in dimensions and greater differences in composition and microstructure enabled the division of the nails into two distinct groups: Type A nails exhibit an as-cast Widmanstätten lamella structure; and Type B nails exhibit $\alpha$ brass grains containing a dendritic microstructure. This may indicate that the two nail types were intended for different purposes, or that the nails were manufactured in different workshops.

Since the zinc concentration is greater than $32 \mathrm{wt} \%$, it is suggested that the zinc used for manufacturing the nails was produced by direct alloying. The nails were used in the cast state. Despite the compositional differences in the lead isotope signatures, the raw material for the production of the nails derived from a common metal source, most probably from Great Britain. Based on the zinc and lead concentrations, it is suggested that the nails were most likely manufactured in the first half of the nineteenth century. Thus, the Akko Tower Wreck is probably the remains of a European merchantman which sank in Akko harbor around the middle of the nineteenth century.

Acknowledgments The underwater excavations (IAA permit G-23/ 2012 and G-78/2013) and research of the Akko Tower Wreck are supported by the Israel Science Foundation (Grant No. 447/12), the Honor Frost Foundation, a Sir Maurice Hatter Fellowship, the Rector and Research Authority of the University of Haifa, and anonymous donors, to whom the authors are grateful. The authors would like to thank H. Kravitz, Microtech LTD (Israel), for his technical metallographic assistance; Z. Barkai, Wolfson Applied Materials Research Centre, Tel Aviv University, for her assistance; M. Bram and N. Cvikel for their help with the hammering experiment; J. B. Tresman for the English editing; and the anonymous reviewers for their valuable comments.

\section{References}

1. M. Dothan, Z. Goldmann, Tell Acco, in New Encyclopaedia of Archaeological Excavations the Holy Land, ed. by E. Stern (Carta, Israel Exploration Society, Jerusalem, 1993), pp. 16-27

2. N. Makhouly, C.N. Johns, Guide to Acre (Government of Palestine, Department of Antiquities, Jerusalem, 1946)

3. B. Masters, Acre, in Encyclopaedia of the Ottoman Empire, ed. by G. Ágoston, B. Masters (Facts on File, New York, 2009), pp. $9-10$

4. A. Cohen, Palestine in the 18th Century: Patterns of Government and Administration (Magnes, Hebrew University, Jerusalem, 1973)
5. R.C. Alderson, Notes on Acre and Some of the Coast Defences in Syria. Papers on Subjects Connected with the Duties of the Corps of Royal Engineers, VI, John Weale, London, 1843

6. R.C. Anderson, Naval Wars in the Levant 1559-1853 (University Press of Liverpool, Liverpool, 1952)

7. C. La Jonquière, L'Expédition d'Egypte, 1798-1801, IV (H. Charles-Lavauzelle, Paris, 1900)

8. A.J. Rustum, Notes on Akka and Its Defences Under Ibrahim Pasha (American University of Beirut, Beirut, 1926)

9. T.H. Molyneux, Expedition to the Jordan and the Dead Sea. J. R. Geog. Soc. Lond. 18, 104-130 (1848)

10. W.F. Lynch, Official Report of the United States Expedition to Explore the Dead Sea and the River Jordan (John Murphy, Baltimore, 1852)

11. W.F. Lynch, Narrative of the Expedition to the River Jordan and the Dead Sea (James Blackwood, Paternoster Row, London, 1855)

12. H. Goren, Sacred, but not surveyed: nineteenth-century surveys of Palestine. Imago Mundi 54, 87-110 (2002)

13. A. Flinder, E. Linder, E.T. Hall, Survey of the ancient harbour of Akko, 1964-1966, in Studies in the Archaeology and History of Ancient Israel, ed. by M. Heltzer, A. Segal, D. Kaufman (Haifa University Press, Haifa, 1992), pp. 199-225

14. A. Raban, A shipwreck from Napoleon's siege of Akko (1799), in The Western Galilee Antiquities, ed. by M. Yedaya (The Ministry of Defense, Tel Aviv, 1986), pp. 195-208 (Hebrew)

15. J.R. Steffy, The Napoleonic wreck: A workshop in ship construction (Unpublished report, 1983)

16. M. McCarthy, Ships' fastenings from sewn boat to steamship (Texas A\&M University Press, College Station, 2005)

17. J. Bayley, The production of brass in antiquity with particular reference to Roman Britain, in 2000 years of Zinc and Brass, ed. by P.T. Craddock (British Museum Research Laboratory, London, 1990), pp. 7-27

18. K.E. Jakielski, M.R. Notis, The metallurgy of Roman medical instruments. Mater. Charact. 45(4), 379-389 (2000)

19. R.F. Tylecote, A History of Metallurgy (The Metals Society, London, 1992)

20. P.T. Craddock, The composition of the copper alloys used by the Greek, Etruscan and Roman civilizations: 3. The origins and early use of brass. J. Archaeol. Sci. 5(1), 1-16 (1978)

21. T. Herbert, J. Wallace, The Cambridge Companion to Brass Instruments (Cambridge University Press, Cambridge, 1997)

22. D. Ashkenazi, D. Cvikel, N. Iddan, E.D. Mentovich, Y. Kahanov, M. Levinstain, Archaeometallurgical study of the brass cases from the Akko 1 Shipwreck. J. Archaeol. Sci. 38(9), 2410-2419 (2011)

23. J.A. Rao, J.B. Rao, S. Kamaluddin, N.R.M.R. Bhargava, Studies on cold workability limits of brass using machine vision system and its finite element analysis. J. Miner. Mater. Charact. Eng. 10(9), 777-803 (2011)

24. M.M. Haque, A.A. Khan, Investigation on structure and properties of brass casting. J. Mater. Sci. Technol. 24(3), 299-301 (2008)

25. P.T. Craddock, The early history of zinc. Endeavour 11(4), 183-191 (1987)

26. L. Glinsman, D. Barbour, Science and art converge at the National Gallery of Art. J. Miner. Met. Mater. Soc. 49(1), 14-17 (1997)

27. D.A. Scott, Metallography and Microstructure of Ancient and Historic Metals (Getty Conservation Institute, Santa Monica, 1991)

28. J. Percy, Metallurgy: the Art of Extracting Metals from Their Ores, and Adapting Them to Various Purpose of Manufacture (John Murray, London, 1864) 
29. J. Day, Brass and zinc in Europe from the Middle Ages until the 19th century, in 2000 years of Zinc and Brass, ed. by P.T. Craddock (British Museum Research Laboratory, London, 1990), pp. $123-148$

30. G.W.R. Ward, The Grove Encyclopaedia of Materials and Techniques in Art (Oxford University Press, New York, 2008)

31. T.H. Rehren, M. Martinón-Torres, Naturam Ars Imitata: European brassmaking between craft and science, in Archaeology, History and Science: Integrating Approaches to Ancient Material, ed. by M. Martinón-Torres, T.H. Rehren (Left Coast Press, Walnut Creek, 2008), pp. 167-188

32. M.B. Mitchiner, C. Mortimer, A.M. Pollard, The chemical compositions of 19th century copper-base English jetons. Br. Numis. J. 57, 77-88 (1987)

33. G. Lesoult, Basic concepts crystal growth and solidification, in ASM Metals Handbook, Volume 15: Casting, ed. by H.J. Frissell (ASM International, Materials Park, 1996), pp. 231-235

34. R. Trivedi, Solidification of single-phase alloys, in ASM Metals Handbook, Volume 15: Casting, ed. by H.J. Frissell (ASM International, Materials Park, 1996), pp. 244-257

35. R.J. Fruehan, Gases in metals, in ASM Metals Handbook, Vol. 15: Casting, ed. by H.J. Frissell (ASM International, Materials Park, 1996), pp. 175-190

36. P. Qiu, C. Leygraf, Initial oxidation of brass induced by humidified air. Appl. Surf. Sci. 258, 1235-1241 (2011)

37. Patents for invention, in Abridgments of the Specifications Relating to Ship Building, Repairing, Sheathing Launching, \& $C$ (George E. Eyre and William Spottiswoode, London, 1862)

38. J.M. Bingeman, J.P. Bethell, P. Goodwin, A.T. Mack, Copper and other sheathing in the Royal Navy. Int. J. Naut. Archaeol. 29(2), 218-229 (2000)

39. D.E. Tyler, W.T. Black, Introduction to copper and copper alloys, in ASM Metals Handbook, Vol. 2: Properties and Selection: Nonferrous Alloys and Special-Purpose Materials, ed. by S.R. Lampman, T.B. Zorc (ASM International, Materials Park, 1990), pp. 759-839

40. G. Wills, Collecting Copper and Brass (Hesperides Press, London, 2008)

41. B. Baretzky, M. Friesel, B. Straumal, Reconstruction of historical alloys for pipe organs brings true baroque music back to life. Mater. Res. Soc. Bull. 32(3), 249-255 (2007)

42. S. Klein, C. Domergue, Y. Lahaye, G.P. Brey, H.M. von Kaenel, The lead and copper isotopic composition of copper ores from the Sierra Morena (Spain). J. Iber. Geol. 35(1), 59-68 (2009)

43. R. Müller, G.P. Brey, H.M. Seitz, S. Klein, Lead isotope analyses on Late Republican sling bullets. Archaeol. Anthropol. Sci. (2014). doi:10.1007/s12520-014-0209-0

44. R.C. Batra, C.H. Kim, Analysis of shear banding in twelve materials. Int. J. Plast. 8(4), 425-452 (1992)

45. K.R. Trethewey, I. Pinwill, The dezincification of free-machining brasses in sea water. Surf. Coat. Technol. 30(3), 289-307 (1987)

46. D. Ashkenazi, D. Cvikel, A. Stern, S. Klein, Y. Kahanov, Metallurgical characterization of brass objects from the Akko 1 shipwreck. Isr. Mater. Charact. 92, 49-63 (2014)

47. J.R. Sinko, R.C. Brooks, Microstructural analysis of brass and zinc nails from the wreckage of a sailing ship. Mater. Charact. 29(2), 259-265 (1992)

48. P.T. Craddock, Medieval copper alloy production and West African bronze analyses-part 1. Archaeometry 27(1), 17-41 (1985)

49. D. Ashkenazi, N. Iddan, O. Tal, Archaeometallurgical characterization of Hellenistic metal objects: the contribution of the bronze objects from Rishon Le-Zion (Israel). Archaeometry 54(3), 528-548 (2012)

50. M. Cottura, B. Appolaire, A. Finel, Y. Le Bouar, Phase field study of acicular growth: role of elasticity in Widmanstätten structure. Acta Mater. 72, 200-210 (2014)
51. R. Garg, S. Ranganathan, S. Suwas, Effect of mode of rolling on development of texture and microstructure in two-phase $(\alpha+\beta)$ brass. Mater. Sci. Eng. A 527(18), 4582-4592 (2010)

52. R. Garg, P.N. Gurao, S. Ranganathan, S. Suwas, Evolution of texture and grain boundary microstructure in two-phase $(\alpha+\beta)$ brass during recrystallization. Philos. Mag. 91(32), 4089-4108 (2011)

53. S. Li, H. Imai, K. Kondoh, Microstructure, phase transformation, precipitation behaviour and mechanical properties of $\mathrm{P} / \mathrm{M}$ $\mathrm{Cu} 40 \mathrm{Zn}-1.0$ wt\% Ti Brass alloy via spark plasma sintering and hot extrusion. J. Mater. Sci. Technol. 29(11), 1018-1024 (2013)

54. J. Perkins, Morphology of Widmanstätten precipitates at early stages of development. Metallography 6(3), 185-193 (1973)

55. N. Stanford, S.P. Bate, Crystallographic variant selection in $\alpha-\beta$ brass. Acta Mater. 53(3), 859-867 (2005)

56. K.F. Hachenberg, The complaint of the Markneukirchen brassinstrument makers about the poor quality of brass from the Rodewisch Foundry, 1787-1795. Hist. Brass Soc. J. 10, 116-145 (1998)

57. D.I. MacLeod, The Surface Analysis of a Brass Plate "Ludwig Leichhardt 1848" and Assessment of Authenticity (Collections Management and Conservation, Western Australian Museum, Perth, 2006)

58. E.W. Boyd, J.C. Charter, J.G. Lancaster, The Suffolk Park shipwreck, northern N.S.W.: Pre-Cook explorers or 19th century trader? Archaeol. Ocean. 29(2), 91-94 (1994)

59. J. Whitewright, J. Satchell, The Archaeology and History of the Flower of Ugie, Wrecked 1852 in the Eastern Solent (Archaeopress, Oxford, 2011)

60. B.M. Rohl, Lead isotope data from the Isotrace Laboratory, Oxford: Archaeometry data base 2, galena from Britain and Ireland. Archaeometry 38(1), 165-180 (1996)

61. E. Newell, 'Copperopolis': the rise and fall of the copper industry in the Swansea District, 1826-1921. Bus. Hist. 32(3), 75-97 (1990)

62. R.J. Edwards, Industrial cost accounting developments in Britain to 1830: a review article. Account Bus. Res. 19(76), 305-317 (1989)

63. O. Brevart, B. Dupré, C.J. Allegre, Metallogenic provinces and the remobilization process studied by lead isotopes: lead-zinc ore deposits from the southern Massif Central. France. Econ. Geol. 77(3), 564-575 (1982)

64. J. Lancelot, G. Sarazin, C.J. Allegre, Composition isotopique du plomb et du soufre des galènes liées aux formations sédimentaires interprétations géologiques et géophysiques. Contrib. Mineral. Petr. 32(4), 315-333 (1971)

65. M. Le Guen, J.J. Orgeval, J. Lancelot, Lead isotope behaviour in a polyphased $\mathrm{Pb}-\mathrm{Zn}$ ore deposit: Les Malines (Cévennes, France). Miner. Deposita 26(3), 180-188 (1991)

66. J.F. Santos Zalduegui, S. García de Madinabeitia, J.I. Gil Ibarguchi, F. Palero, A lead isotope database: The Los PedrochesAlcudia area (Spain): implications for archaeometallurgical connections across Southwestern and Southeastern Iberia. Archaeometry 46(4), 625-634 (2004)

67. M.A. HuntOrtiz, Prehistoric Mining and Metallurgy in South West Iberian Peninsula (BAR International Series 1188, Oxford, 2003)

68. F. Tornos, M. Chiaradia, Plumbotectonic evolution of the Ossa Morena zone, Iberian Peninsula: tracing the influence of mantlecrust interaction in ore-forming processes. Econ. Geol. 99(5), 965-985 (2004)

69. E. Marcoux, J.-M. Leistel, F. Sobol, J.-P. Milesi, J.-L. Lescuyer, $\mathrm{X}$. Leca, Signature isotopique du plomb des amas sulfurés de la province de Huelva, Espagne. Conséquences métallogéniques et géodynamiques. Comptes rendus des séances de l'Académie des sciences. Série 2. Mécanique, physique, chimie, sciences de la terre, sciences de l'univers 314(13), 1469-1476 (1992) 
70. E. Marcoux, Lead isotope systematics of the giant massive sulphide deposits in the Iberian Pyrite belt. Miner. Deposita 33, 45-58 (1998)

71. J.L. Lescuyer, J.M. Leistel, E. Marcoux, J.P. Milési, D. Thiéblemont, Late Devonian-early Carboniferous peak sulphide mineralization in the Western Hercynides. Miner. Deposita 33, 208-220 (1998)

72. Z. Stos-Gale, N.H. Gale, J. Houghton, R. Speakman, Lead isotope data from the Isotrace Laboratory, Oxford: Archaeometry data base 1, Ores from the Western Mediterranean. Archaeometry 37(2), 407-415 (1995)

73. C. Pomiès, A. Cocherie, C. Guerrot, E. Marcoux, J. Lancelot, Assessment of the precision and accuracy of lead-isotope ratios measured by TIMS for geochemical applications: example of massive sulphide deposits (Rio Tinto, Spain). Chem. Geol. 144, 137-149 (1998)

74. S. Klein, C. Domergue, Y. Lahaye, G.P. Brey, H.-M. von Kaenel, Ancient copper mines of the Iberian Peninsula: lead and copper isotope analysis of copper ores by MC-ICP-MS. Minas de cobre antiguas de la península Ibérica. Análisis de los isotopos de plomo y de cobre de los minerales de cobre por MC-ICP-MS. J. Iber. Geol. 35(1), 59-68 (2009)

75. J. Horner, F. Neubauer, W.H. Paar, W. Hansmann, V. Koeppel, $\mathrm{K}$. Robl, Structure, mineralogy, and $\mathrm{Pb}$ isotopic composition of the As-Au-Ag deposit Rotgülden, Eastern Alps (Austria): significance for formation of epigenetic ore deposits within metamorphic domes. Miner. Deposita 32, 555-568 (1997)

76. V. Köppel, E. Schroll, Lead isotopes of palaeozoic, stratabound to stratiform Galena bearing sulfide deposits of the Eastern Alps (Austria): implications for their geotectonic setting. Schweiz. Mineral. Petrogr. Mitt. 63, 347-360 (1983)

77. V. Köppel, E. Schroll, Bleiisotope und Remobilisation von Erzlagerstätten, in Ore Mobilization in the Alps and in SE Europe, ed. by W.E. Petrascheck (Springer, Wien, 1983), pp. 39-51

78. V. Köppel, E. Schroll, Herkunft des $\mathrm{Pb}$ der triassischen $\mathrm{Pb}-\mathrm{Zn}$ Vererzungen in den Ost- und Südalpen Resultate bleiisotopengeochemischer Untersuchungen. Arch. F. Lagerst. Forsch. Geol. B-A 6, 215-222 (1985) 